\title{
Zeolites at high pressure: A review
}

\author{
G. D. GATTA ${ }^{1, *}$ AND Y. LeE ${ }^{2}$
}

1 Dipartimento di Scienze della Terra, Università degli Studi di Milano, Via Botticelli 23, I-20133 Milano, Italy

2 Department of Earth System Sciences, Yonsei University, Seoul 120749, Korea

[Received 17 May 2013; Accepted 8 September 2013; Associate Editor: F. C. Hawthorne]

\section{ABSTRACT}

This is a review of the elastic behaviour and pressure $(P)$-induced structural evolution of zeolites and presents a comparative analysis of the deformation mechanisms of the $\mathrm{Si} / \mathrm{Al}$-framework and the rearrangement of the extra-framework species in response to applied pressure. The interaction between $P$-transmitting fluids and zeolites, which can lead to phenomena such as ' $P$-induced over-hydration', is described. The comparative elastic analysis and the high- $P$ structural data of zeolites reported so far allow us to make some generalizations: (1) The range of compressibility among this class of openframework silicates is large, with bulk moduli ranging between 15 and $70 \mathrm{GPa}$; (2) Microporosity does not necessarily imply high compressibility, as several zeolites are less compressible than other nonzeolitic rock-forming minerals; (3) Compressibilities of zeolites do not seem to be directly related to microporosity, at least if we model microporosity with the 'framework density'; (4) The flexibility observed in zeolites under hydrostatic compression is mainly governed by tilting of rigid tetrahedra around $\mathrm{O}$ atoms that behave as hinges within the framework. Pressure-induced tilting commonly leads to continuous rearrangement of the framework without any phase transition. More rarely, tilting induces displacive phase transitions and isothermal $P$-induced reconstructive phase transitions (i.e. with change in framework topology), have not been reported in this class of materials; (5) Deformation mechanisms in response to applied pressure are generally dictated by the topological configuration of the framework rather than the $\mathrm{Si} / \mathrm{Al}$-distribution or the extra-framework content. The channel content governs the compressibility of the cavities, leading to different unit-cell-volume compressibilities in isotypic structures.

KEYWORDs: zeolites, open-framework structures, high pressure, elastic behaviour, compressibility.

\section{Introduction}

Zeolites are a class of 'microporous materials' characterized by open-structures with cavities (i.e. in the form of channels or cages) with free diameters smaller than $20 \AA$. Natural or synthetic materials with pores larger than $20 \AA$ are 'mesoporous materials'. In Nature, zeolites with $\mathrm{SiO}_{4}-\mathrm{AlO}_{4}-\mathrm{PO}_{4}$-tetrahedra form open frameworks; polar molecules (in particular $\mathrm{H}_{2} \mathrm{O}$ ) and monovalent or divalent cations, which are commonly exchangeable, are the extra-framework species. The tetrahedral framework may be

* E-mail: diego.gatta@unimi.it

DOI: 10.1180/minmag.2014.078.2.04 interrupted by $(\mathrm{OH}, \mathrm{F})$ groups; these occupy tetrahedral apexes that are not shared with adjacent tetrahedra. In hydrated zeolites, dehydration occurs at temperatures of $<400^{\circ} \mathrm{C}$ and is reversible (Coombs et al., 1997). The general formula for common natural $\mathrm{Si} / \mathrm{Al}$-zeolites is as follows: $(\mathrm{Li}, \mathrm{Na}, \mathrm{K})_{x}(\mathrm{Ca}, \mathrm{Sr}, \mathrm{Ba})_{y}\left[\mathrm{Al}_{(x+2 y)} \mathrm{Si}_{n-(x+2 y)}\right.$ $\left.\mathrm{O}_{2 n}\right] \cdot m \mathrm{H}_{2} \mathrm{O}$ (usually with $m<n$ ).

The microporous nature of zeolites is reflected in their low framework density (FD), defined by the number of $\mathrm{T}$ atoms per $1000 \AA^{3}$ (Baerlocher et

This paper is published as part of a special issue of Mineralogical Magazine, Volume 78(2), 2014, in celebration of the International Year of Crystallography. 
al., 2007). For zeolites, FD is generally $<20.5 \mathrm{~T} / 1000 \AA^{3}$. In 'denser' framework silicates (e.g. feldspars, feldspathoids, quartz), FD is $>21.3 \mathrm{~T} / 1000 \AA^{3}$.

Natural zeolites usually occur as secondary minerals in several geological environments in the Earth's crust. An overview of the occurrence of zeolites in sedimentary rocks is found in Hay and Sheppard (2001), in "closed" and "open" hydrological systems by Langella et al. (2001) and Sheppard and Hay (2001), respectively, in burial diagenesis and low-grade metamorphic rocks by Utada (2001a) and in hydrothermally altered rocks by Utada (2001b).

The selective cation-exchange capacity, along with $T$-induced reversible hydration/dehydration and the catalytic activity (mainly promoted by Brønsted acid sites) of zeolites have made this class of natural or synthetic materials an object of attention for their advanced technological applications, spanning from water treatment, soil remediation, cements production, gas separation, animal feeding, biomedical and veterinary applications to catalysis in the petroleum industry and nuclear-waste processing (e.g. Komarneni, 1985; Mumpton, 1999; Kalló, 2001; Maxwell and Stork, 2001; Ming and Allen, 2001; Bish et al., 2003; Ackley et al., 2003, Colella, 2011). As a consequence, zeolites are an important bulk commodity: the world production of natural zeolites in 2012 was $2,800,000$ tons and the consumption of synthetic zeolites was $\sim 1,900,000$ tons (US Geological Survey, 2013). World reserves of natural zeolites have not been estimated. In the USA, resources may approach 10 trillion tons for zeolite-rich deposits (US Geological Survey, 2013).

Over the last 60 years, many experiments have addressed the behaviour of zeolites in response to applied temperature (e.g. Bish and Carey, 2001; Cruciani, 2006 and references therein). The mechanisms of $T$-induced dehydration, cation migration and the rearrangement of extra-framework species have been investigated extensively, mainly by in situ single-crystal or powder X-ray/ neutron-diffraction (e.g. Bish and Carey, 2001; Pabalan and Bertetti, 2001).

On the other hand, experiments on zeolites at high pressure have only been carried out in the last $10-15 \mathrm{y}$, shedding new insights into elastic behaviour and phase stability in response to changing pressure, coupled with $P$-induced deformation mechanisms at the atomistic level (e.g. Gatta, 2008, 2010a,b and references therein),
$P$-induced over-hydration and its corresponding volume expansion (e.g. Lee et al., 2002a,b), $P$-induced amorphization processes (e.g. Gillet et al., 1996; Huang and Havenga, 2001; Rutter et al., 2001; Greaves et al., 2003; Gulìn-Gonzàles and Suffritti, 2004; Goryainov, 2005) along with the effect of pressure on the ionic conductivity of zeolites (e.g. Secco and Huang, 1999; Rutter et al., 2000).

The aim of this work is a synthesis of previously published data on the behaviour of natural (and some synthetic) zeolites at high pressure, in order to understand: (1) the relationship between compressibility and microporosity; (2) the framework flexibility, through deformation mechanisms at the atomistic level and (3) the different roles played by framework (i.e. Si/Alordering, different cross-linking of the "building block unit') and extra-framework configurations (i.e. nature of cations and absorbed molecules, ionic valence, ionic radii, coordination number) on the behaviour of zeolites. The 'pressureinduced over-hydration and volume expansion' in natrolite will also be discussed.

\section{In situ high-pressure experiments on zeolites: technical aspects}

In situ high-pressure experiments on zeolites have been done by: (1) single-crystal and powder X-ray diffraction (XRD) and infrared/Raman spectroscopy adopting the Merrill-Bassett (or modified Merrill-Bassett) diamond-anvil cell (DAC) (Merrill and Bassett, 1974; Miletich et al., 2000), and (2) neutron powder diffraction using the large-volume Paris-Edinburgh press (i.e. Besson et al., 1992; Colligan et al., 2005; Seryotkin et al., 2005). Experiments on the elastic parameters of some zeolites at room conditions have been done by Brillouin-scattering spectroscopy (e.g. analcime and pollucite, Sanchez-Valle et al., 2005, 2010).

High-pressure experiments are usually undertaken with a $P$-transmitting fluid, in order to compress hydrostatically the material under investigation (Angel et al., 2007). The behaviour of open-framework materials may be strongly influenced by the nature of the $P$-transmitting fluid used for the experiments: i.e. "penetrating" or "non-penetrating" $P$-media (sensu Gatta, 2008). "Penetrating fluids" contain molecules able to penetrate into the zeolitic micropores in response to applied pressure, implying a strong effect on the elastic response, along with the 
$P$-induced deformation mechanisms at the atomic level. Elemental gaseous media at ambient conditions (e.g. $\mathrm{He}, \mathrm{N}, \mathrm{Ne}, \mathrm{Ar}, \mathrm{Xe}$ ) and small molecules (e.g. $\mathrm{H}_{2} \mathrm{O}, \mathrm{CO}_{2}$ ) are potentially penetrating media. In contrast, complex (and larger) molecules usually used as $P$-transmitting media (e.g. mixed methanol:ethanol $=4: 1$, glycerol, various grades of silicone-oils, isopropanol, perfluorether, fluorinert FC-75, Angel et al., 2007; Klotz et al., 2009), or solid media at room conditions (e.g. $\mathrm{NaCl}, \mathrm{KCl}$ ), can be considered as nominally non-penetrating media.

$P$-induced penetrability is controlled by several variables: (1) the "free diameters" (Baerlocher et al., 2007) of the framework channels; (2) the nature of the channel content and (3) the partial pressure of the penetrating molecule, if mixed with other non-penetrating molecules (e.g. $P_{\mathrm{H}_{2} \mathrm{O}}$ in a mixture of methanol:ethanol: $\mathrm{H}_{2} \mathrm{O}=16: 3: 1$, usually used as hydrostatic $P$-fluids up to $10 \mathrm{GPa}$, Angel et al., 2007).

Pressure-induced penetration of 'external' molecules through zeolitic micropores was incidentally observed (and not entirely understood) in the first experiments performed (i.e. zeolite Na-A, Hazen, 1983; Hazen and Finger, 1984). The first structure-refinements that showed, unambiguously, the $P$-induced "overhydration effect" in natrolite and "natrolite-like" materials (i.e. $\mathrm{K}_{16} \mathrm{Ga}_{16} \mathrm{Si}_{24} \mathrm{O}_{80} \cdot 12 \mathrm{H}_{2} \mathrm{O}$ ) were reported by Lee et al. $(2002 a, b)$, through the selective sorption of $\mathrm{H}_{2} \mathrm{O}$ molecules from the pressure fluid, giving rise to high-pressure $(\mathrm{H} P)$ over-hydrated phases. As a consequence of the $\mathrm{H} P$ over-hydration effect, natrolite-like zeolites experience a spectacular $P$-induced volume expansion. Later, experiments addressed the $P$ induced penetration of 'external' molecules in natural or synthetic zeolites with different frameworks, opening a new area in the crystal chemistry of this class of materials (e.g. Lee et al., 2002a,b, 2004a,b,c, 2010, 2011; Likhacheva et al., 2006, 2007; Colligan et al., 2005; Seryotkin et al., 2005; Ori et al., 2008a). The experiments on over-hydration effects and (more in general) $P$-induced penetration of external molecules, showed that this unusual phenomenon can give rise to (1) new extra-framework sites, changing the configuration of the extra-framework species significantly (as in fibrous zeolites or in laumontite, Lee et al., 2002a, 2004b) or (2) increasing the occupancy factors of sites partly occupied at room $P$ without new sites (e.g. Ori et al., 2008a, where a hydrous $P$ - transmitting fluid was used). In the first case, a $P$ induced expansion of the unit-cell volume is commonly observed, with a discontinuity in the evolution of $V v s$. $P$. In the second case, the evolution of $V$ vs. $P$ does usually not involve a discontinuity: the over-hydration effect seems to be a continuous process, toward an upper limit where all the extra-framework sites are fully occupied (e.g. Ori et al., 2008a).

For experiments on zeolites at high pressure in DAC, $P$-calibration involved detecting the shift in the $\mathrm{R}_{1}$ emission line of ruby chips (included in the compression chamber, $P$-uncertainty: $\pm 0.05 \mathrm{GPa}$, Mao et al., 1986) and/or with the compressibility pattern of quartz (i.e. with quartz used as an internal standard in the compression chamber; $P$ uncertainty: <0.01 GPa, Angel et al., 1997). Quartz was only used as an internal standard for single-crystal experiments. $P$-calibration for the neutron-diffraction experiments with the ParisEdinburgh large-volume press involved $\mathrm{Pb}$ as an internal standard (Colligan et al., 2005) and using the calibration curve of the ILL hydraulic-press load vs. $P$ (Seryotkin et al., 2005).

The description of the behaviour of a crystalline material in response to applied pressure is based on the analysis of (1) its compressional behaviour and phase stability and (2) the $P$ induced principal deformation mechanisms at the atomic level. The compressional behaviour of a material can be described on the basis of the evolution of its lattice parameters with pressure, whereas the description of mechanisms at the atomic level requires structure refinement at high pressure. The majority of $\mathrm{H} P$ experiments on zeolites based on in situ single-crystal XRD allowed measurement of precise and accurate lattice parameters along with $\mathrm{H} P$-structural refinements (e.g. Gatta et al., 2004a,b; Lotti et $a l .$, 2012). In contrast, the low quality of the $\mathrm{H} P$ powder-diffraction data allowed refinement of the lattice parameters at different pressures, but was often not sufficient for structural refinement. On this basis, HP powder-diffraction studies were often augmented with distance least squares (DLS) simulations or ab initio molecular dynamics (e.g. Ballone et al., 2002; Ferro et al., 2002; Lee et al., 2004a; Fois et al., 2005, 2008).

\section{Systematics of the high-pressure behaviour of zeolites}

The large number of framework topologies of natural and synthetic zeolites (currently 206 
framework types, http://www.iza-online.org) impedes a comprehensive analysis of their comparative elastic behaviour, along with the $P$ induced deformation mechanisms at the atomic level. In this light and considering our main interests on natural zeolites (or their synthetic counterparts), we have selected a classification scheme for natural zeolites (Gottardi and Galli, 1985), slightly modified by Armbruster and Gunter (2001), in which zeolites are divided into: (1) zeolites with $\mathrm{T}_{5} \mathrm{O}_{10}$ units (or 'fibrouszeolites group'); (2) zeolites with chains of corner-sharing four-membered rings; (3) zeolites with chains of edge-sharing four-membered rings; (4) zeolites with six-membered rings; (5) zeolites with $\mathrm{T}_{8} \mathrm{O}_{16}$ units (or zeolites of the "mordenite group'); (6) zeolites with $\mathrm{T}_{10} \mathrm{O}_{20}$ units (or zeolites of the 'heulandite group'). A further section is devoted to zeolites (rare or absent in Nature) that do not belong to the aforementioned groups.

\section{Group 1: zeolites with $T_{5} \mathrm{O}_{10}$ units ('fibrous- zeolites group')}

The crystal structures of 'fibrous zeolites' are built from $\mathrm{T}_{5} \mathrm{O}_{10}$ units (i.e. $4=1$ 'secondary building units' (SBU), Armbruster and Gunter, 2001; Baerlocher et al., 2007). These units form chains with tetragonal topological symmetry. Different combinations of these chains form the three topologies of the fibrous-zeolite frameworks: EDI - edingtonite (ideally $\mathrm{Ba}_{2} \mathrm{Al}_{4} \mathrm{Si}_{6} \mathrm{O}_{20} \cdot 8 \mathrm{H}_{2} \mathrm{O}$ ), NAT - natrolite (ideally $\mathrm{Na}_{16} \mathrm{Al}_{16} \mathrm{Si}_{24} \mathrm{O}_{80} \cdot 16 \mathrm{H}_{2} \mathrm{O}$ ) and $\mathrm{THO}$ - thomsonite (ideally $\mathrm{Na}_{4} \mathrm{Ca}_{8} \mathrm{Al}_{20} \mathrm{Si}_{20} \mathrm{O}_{80} \cdot 24 \mathrm{H}_{2} \mathrm{O}$ ). Scolecite (ideally $\mathrm{Ca}_{8} \mathrm{Al}_{16} \mathrm{Si}_{24} \mathrm{O}_{80} \cdot 24 \mathrm{H}_{2} \mathrm{O}$ ) and mesolite (ideally $\mathrm{Na}_{16} \mathrm{Ca}_{16} \mathrm{Al}_{48} \mathrm{Si}_{72} \mathrm{O}_{240} \cdot 64 \mathrm{H}_{2} \mathrm{O}$ ) have a NAT framework type. The configuration of the three framework types seems to be similar when viewed down [001] (i.e. down the direction of the chains). Viewed in a direction perpendicular to the SBU-chains, the fibrous-zeolite frameworks have two different systems of channels: channels of eight-membered rings along [001] and [110] in EDI, [110] in NAT (scolecite and mesolite) and [010] in THO. The fibrous-zeolite group is probably the most studied group at high pressure. This is a consequence of (1) relatively simple crystal structures (compared to other zeolite groups), (2) availability of single crystals suitable for in situ XRD experiments and (3) high crystallinity of all the members of this group. Gatta $(2005,2008)$ reviewed the comparative compressibility of members of the fibrous-zeolite group based on a series of previously published experiments (by in situ single-crystal and synchrotron/neutron powder-diffraction data, i.e. Ballone et al., 2002; Comodi et al., 2002; Lee et al., 2002a,b, 2004a, 2005; Gatta and Wells, 2004; Gatta et al., 2004a,b; Colligan et al., 2005; Likhacheva et al., 2006, 2007). Gatta (2005, 2008) showed that: (1) The volume compressibility of zeolites belonging to this group is controlled by the nature of the extra-framework content. (2) The elastic anisotropy (represented by the axial compressibilities) is influenced by the (tetragonal) topological symmetry of the framework. (3) Ordering in the Si/Al-distribution does not imply any significant effect on the unit-cell volume compressibility. However, it can influence the elastic behaviour of the framework (e.g. represented by the SBU compressibility), but the effect is evident only on the elastic anisotropy and it is not strong enough to be reflected in the unitcell compressibility. (4) In all fibrous zeolites, the compression is accommodated by the same main deformation mechanism, represented by cooperative anti-rotation of the SBU around the chain axis (Fig. 1). This mechanism reduces the free volume of the channels parallel to the SBU-chains (Fig. 1) and seems to be independent of the nature of the extra-framework species, of the SBU-chains cross-linking geometry and of the $\mathrm{Si} /$ Al-distribution.

Fibrous zeolites are the first microporous materials with a $P$-induced over-hydration effect confirmed by in situ $\mathrm{H} P$-structure refinement. The first structural evidence of $P$-induced overhydration was reported for natrolite and the natrolite-type $\mathrm{K}_{16} \mathrm{Ga}_{16} \mathrm{Si}_{24} \mathrm{O}_{80} \cdot 12 \mathrm{H}_{2} \mathrm{O}$ compound by in situ synchrotron powder-diffraction experiments using a hydrous penetrating $P$-transmitting fluid (i.e. methanol:ethanol:water $=16: 3: 1$ ). Lee et al. $(2002 a, b)$ found that natrolite (i.e. $\mathrm{Na}_{16} \mathrm{Al}_{16} \mathrm{Si}_{24} \mathrm{O}_{48} \cdot 16 \mathrm{H}_{2} \mathrm{O}$ at ambient conditions) can be 'super-hydrated' at pressures in excess of 1.2 $\mathrm{GPa}$ and that discrete amounts of extra $\mathrm{H}_{2} \mathrm{O}$ molecules are selectively absorbed from the $P$-fluid to its channel to double the water content to $\mathrm{Na}_{16} \mathrm{Al}_{16} \mathrm{Si}_{24} \mathrm{O}_{48} \cdot 32 \mathrm{H}_{2} \mathrm{O}$. The hydrogen-bonding network of super-hydrated natrolite was then confirmed by in situ $\mathrm{HP}$ neutron powder diffraction (Colligan et al., 2005). Detailed study in the $P$-range $1-1.2 \mathrm{GPa}$ revealed the existence of 'ordered paranatrolite', which exhibits an intermediate $\mathrm{H}_{2} \mathrm{O}$ content of $\mathrm{Na}_{16} \mathrm{Al}_{16} \mathrm{Si}_{24} \mathrm{O}_{48} \cdot 24 \mathrm{H}_{2} \mathrm{O}$ yet has the largest unitcell expansion by $\sim 7 \%$ compared to natrolite 

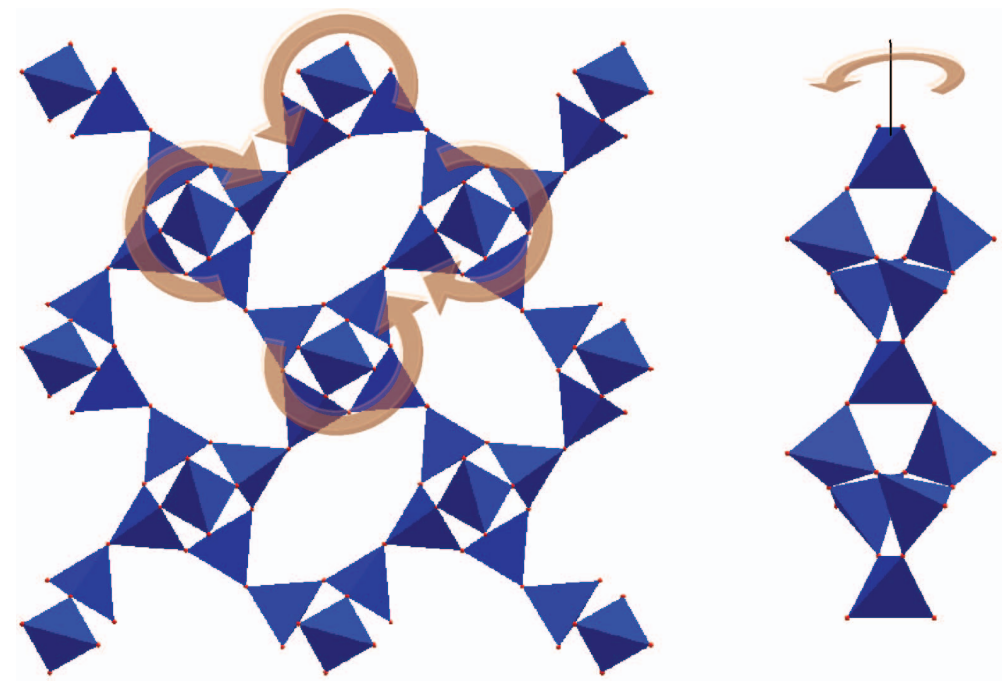

FIG. 1. EDI framework type: SBU chains extend along [001] and undergo cooperative anti-rotation in response to applied pressure. The deformation mechanism leads to compression of the channels of eight-membered rings parallel to $[001]$.

stable at room $P$. The density of $\mathrm{Na}_{16} \mathrm{Al}_{16}$ $\mathrm{Si}_{24} \mathrm{O}_{48} \cdot 24 \mathrm{H}_{2} \mathrm{O}$ is lower than both $\mathrm{Na}_{16} \mathrm{Al}_{16} \mathrm{Si}_{24}$ $\mathrm{O}_{48} \cdot 16 \mathrm{H}_{2} \mathrm{O}$ and $\mathrm{Na}_{16} \mathrm{Al}_{16} \mathrm{Si}_{24} \mathrm{O}_{48} \cdot 32 \mathrm{H}_{2} \mathrm{O}$, due to an unusual seven-fold coordination environment of $\mathrm{Na}^{+}$by alternating the population of $\mathrm{H}_{2} \mathrm{O}$ along the channel (e.g. $\mathrm{Na}-\mathrm{OH}_{2}-\mathrm{Na}$ bonds). Interestingly, the $P$-induced over-hydration effect is completely reversible in natrolite but not in natrolite-type $\mathrm{K}_{16} \mathrm{Ga}_{16} \mathrm{Si}_{24} \mathrm{O}_{80} \cdot 12 \mathrm{H}_{2} \mathrm{O}$. The $P$-induced penetration of $\mathrm{H}_{2} \mathrm{O}$ in fibrous zeolites was also observed in scolecite and thomsonite (Likhacheva et al., 2006, 2007) but not in edingtonite (Gatta et al., 2004b), probably because the large Ba-polyhedron in edingtonite hinders further penetration of $\mathrm{H}_{2} \mathrm{O}$ molecules.

The phenomena observed in fibrous zeolites when compressed in hydrous $P$-fluids led Lee et al. $(2010,2011)$ to investigate the $P$-induced penetration of $\mathrm{Ar}$ and $\mathrm{CO}_{2}$ in natrolite. Starting from natrolite of composition $\mathrm{Na}_{16} \mathrm{Al}_{16} \mathrm{Si}_{24} \mathrm{O}_{48} \cdot 16 \mathrm{H}_{2} \mathrm{O}$, Lee et al. (2010) showed that the incorporation of significant amounts of Ar under moderate pressure- and temperature-conditions resulted in $\mathrm{Na}_{16} \mathrm{Al}_{16} \mathrm{Si}_{24} \mathrm{O}_{80} \cdot 16 \mathrm{H}_{2} \mathrm{O} \cdot 6 \mathrm{Ar}$ stable at $P$ $>3.0-3.5 \mathrm{GPa}$. This high- $P$ phase has $\sim 6.5 \%$ larger unit-cell volume than the starting natrolite. Its structure is related to the aforementioned $\mathrm{Na}_{16} \mathrm{Al}_{16} \mathrm{Si}_{24} \mathrm{O}_{80} \cdot 24 \mathrm{H}_{2} \mathrm{O}$. In other words, $\mathrm{Ar}$ tends to lie where some of the $\mathrm{H}_{2} \mathrm{O}$ sites occur in
$\mathrm{Na}_{16} \mathrm{Al}_{16} \mathrm{Si}_{24} \mathrm{O}_{80} \cdot 24 \mathrm{H}_{2} \mathrm{O}$. In the structure of $\mathrm{Na}_{16} \mathrm{Al}_{16} \mathrm{Si}_{24} \mathrm{O}_{80} \cdot 16 \mathrm{H}_{2} \mathrm{O} \cdot 6 \mathrm{Ar}, \mathrm{Na}^{+}$remain sixcoordinated with the $\mathrm{Ar}-\mathrm{Na}$ distances between 2.90-3.22 $\AA$ and the $\mathrm{Ar}-\mathrm{O}$ distances at $~ 3.24 \AA$, in the configuration shown in Fig. 2. Argon only interacts via short-range van der Waals forces. Using $\mathrm{CO}_{2}$ as the penetrating $P$-medium, natrolite transforms to $\mathrm{Na}_{16} \mathrm{Al}_{16} \mathrm{Si}_{24} \mathrm{O}_{80} \cdot 16 \mathrm{H}_{2} \mathrm{O} \cdot 8 \mathrm{CO}_{2}$ at $1.5 \mathrm{GPa}$. The $\mathrm{CO}_{2}$ penetration leads to unit-cell volume expansion of $\sim 6.8 \%$ and the new material contains $\sim 12$ wt. $\%$ of $\mathrm{CO}_{2}$ and has monoclinic s y m m e try $(C c)$. S u r prisingly, $\mathrm{Na}_{16} \mathrm{Al}_{16} \mathrm{Si}_{24} \mathrm{O}_{80} \cdot 16 \mathrm{H}_{2} \mathrm{O} \cdot 8 \mathrm{CO}_{2}$ seems meta-stable at room $P$ after $P$-release, even after an equilibration time of $1 \mathrm{~h}$. The $\mathrm{H} P$-structure refinements show that the inserted $\mathrm{CO}_{2}$ molecules lie in a plane almost perpendicular to the channel. The distribution of extra-framework cations remains unchanged in the presence of $\mathrm{CO}_{2}$ in the channel, whereas migration of the $\mathrm{H}_{2} \mathrm{O}$ molecules (towards one side of the channel) is observed. $\mathrm{CO}_{2}$ interacts with both $\mathrm{Na}$ and $\mathrm{H}_{2} \mathrm{O}$. The two independent $\mathrm{O}$ sites of the $\mathrm{CO}_{2}$ molecule form a helical arrangement together with the $\mathrm{O}$ sites of the two independent $\mathrm{H}_{2} \mathrm{O}$ molecules, confining cations along the channel. The coordination environment of $\mathrm{Na}$ in $\mathrm{Na}_{16} \mathrm{Al}_{16} \mathrm{Si}_{24} \mathrm{O}_{80} \cdot 16 \mathrm{H}_{2} \mathrm{O} \cdot 8 \mathrm{CO}_{2}$ is shown in Fig. 2.

The $P$-induced penetration of $\mathrm{H}_{2} \mathrm{O}, \mathrm{Ar}$ and $\mathrm{CO}_{2}$, which leads to a significant volume 

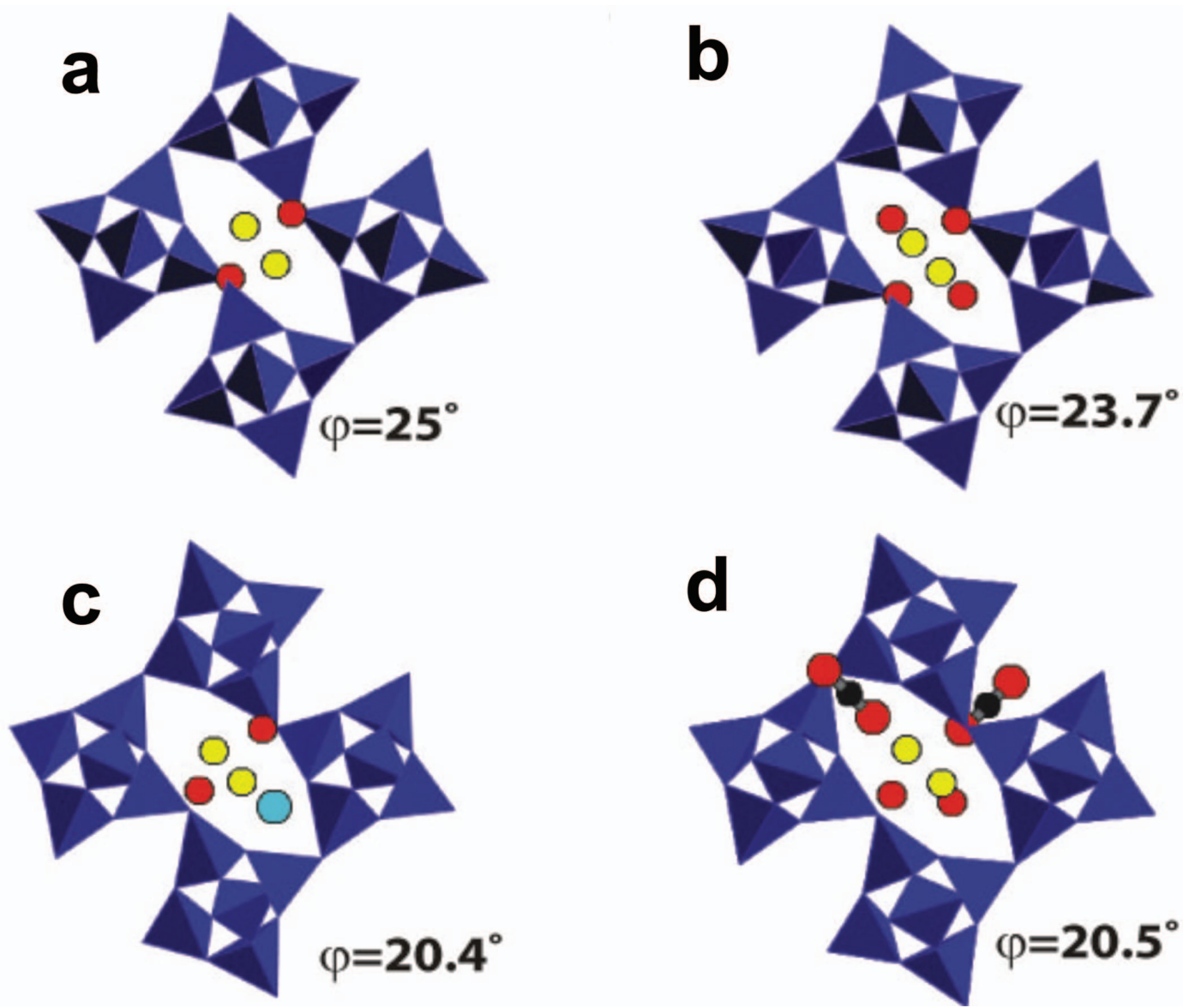

FIG. 2. Configuration of the chain rotation and extra-framework species in natrolite $(a)$ at ambient conditions $\left(\mathrm{Na}_{16} \mathrm{Al}_{16} \mathrm{Si}_{24} \mathrm{O}_{48} \cdot 16 \mathrm{H}_{2} \mathrm{O}\right),(b)$ at $1.5 \mathrm{GPa}$ in $\mathrm{H}_{2} \mathrm{O} P$-medium $\left(\mathrm{Na}_{16} \mathrm{Al}_{16} \mathrm{Si}_{24} \mathrm{O}_{48} \cdot 32 \mathrm{H}_{2} \mathrm{O}\right),(c)$ at $3.1 \mathrm{GPa}$ in $\mathrm{Ar} P$ medium $\left(\mathrm{Na}_{16} \mathrm{Al}_{16} \mathrm{Si}_{24} \mathrm{O}_{80} \cdot 16 \mathrm{H}_{2} \mathrm{O} \cdot 6 \mathrm{Ar}\right)$ and $(d)$ at $1.5 \mathrm{GPa}$ in $\mathrm{CO}_{2} P$-medium $\left(\mathrm{Na}_{16} \mathrm{Al}_{16} \mathrm{Si}_{24} \mathrm{O}_{80} \cdot 16 \mathrm{H}_{2} \mathrm{O} \cdot 8 \mathrm{CO}_{2}\right)$. Yellow and red balls depict $\mathrm{Na}^{+}$and $\mathrm{H}_{2} \mathrm{O}$ oxygen atoms, respectively. Argon atoms and $\mathrm{CO}_{2}$ molecules are denoted by a large azure ball and two red balls connected linearly via black balls, respectively. The rotation of the chain SBUs around the channel $c$ axis are quantified using the $\varphi$ angle which is the mean of the angles between the sides of the quadrilateral around the SBUs and the $a$ and $b$ axes.

expansion, is coupled with a cooperative rotation of the SBU around the chain axis in a way that makes the channels more circular in the expanded form. Whereas $\mathrm{H}_{2} \mathrm{O}$ is able to penetrate at high- $P$ through the channel of eight-membered rings in natrolite without the effect of temperature, $\mathrm{Ar}$ and $\mathrm{CO}_{2}$ can penetrate through the voids only after annealing at moderate $T$ (i.e. $60^{\circ} \mathrm{C}$ for $10 \mathrm{~h}$ for $\mathrm{Ar}$, $110^{\circ} \mathrm{C}$ for $1 \mathrm{~h}$ for $\mathrm{CO}_{2}$ ). In a recent study by Lee et al. (2012), pressure-induced volume expansion was used to exchange and immobilize large aliovalent cations in natrolite channels.

\section{Group 2: zeolites with chains of corner-sharing} four-membered rings

Zeolites of the ANA-framework type, i.e. analcime (ideally $\mathrm{Na}_{16} \mathrm{Al}_{16} \mathrm{Si}_{32} \mathrm{O}_{96} \cdot 16 \mathrm{H}_{2} \mathrm{O}$ ), leucite (ideally $\mathrm{K}_{16} \mathrm{Al}_{16} \mathrm{Si}_{32} \mathrm{O}_{96}$ ), wairakite (ideally $\mathrm{Ca}_{8} \mathrm{Al}_{16} \mathrm{Si}_{32} \mathrm{O}_{96} \cdot 16 \mathrm{H}_{2} \mathrm{O}$ ) and pollucite (ideally $(\mathrm{Cs}, \mathrm{Na})_{16} \mathrm{Al}_{16} \mathrm{Si}_{32} \mathrm{O}_{96} \cdot 16 \mathrm{H}_{2} \mathrm{O}$ ), contain chains of 'corner-sharing four-membered rings' and have been studied at high pressure. Along with the four-membered ring, the ANA-framework type has six-membered rings of tetrahedra (i.e. 4 and 6 SBU, Armbruster and Gunter 2001; 
Baerlocher et al., 2007) and combine to have topological symmetry $\operatorname{Ia} \overline{3} d$ (Baerlocher et al., 2007). Due to the disordered Si/Al-distribution in the framework, analcime and pollucite have general symmetry $I a \overline{3} d$ at ambient conditions. Leucite has partial $\mathrm{Si} / \mathrm{Al}$-ordering in the framework and its general symmetry is lowered to tetragonal $\left(I 4_{1} / a\right)$. Wairakite has an ordered Si/Aldistribution and its general symmetry is further reduced to monoclinic $(I 2 / a)$. The degree of $\mathrm{Si} / \mathrm{Al}-$ ordering can be tuned in analcime, which leads to the occurrence of cubic, tetragonal and orthorhombic analcime in Nature (Mazzi and Galli, 1978; Hazen and Finger, 1979). The first experiment on the high-pressure behaviour of natural analcime was reported by Hazen and Finger (1979) and, more recently, by Gatta et al. (2006) by in situ single-crystal XRD. Analcime has a first-order phase transition at $\sim 1 \mathrm{GPa}$ from the low- $P$ form (cubic, tetragonal or orthorhombic) to the triclinic high- $P$ form $(P \overline{1}$, Gatta et al., 2006). Elastic analysis shows an unusual behaviour: the compressibility of the $\mathrm{HP}$-polymorph is higher than that of the low- $P$ polymorph (Gatta et al., 2006). The structure refinements of the low- and high- $P$ polymorphs (Gatta et al., 2006) show that the $P$-induced phase transition is displacive in character, with the main deformation mechanisms governed by tilting of tetrahedra. The relaxation mechanisms lead to a strong distortion of the four- and six-membered rings, along with a rearrangement of the extra-framework species. Gatta et al. (2008a, 2009a) investigated the highpressure behaviour of leucite and pollucite, respectively and Ori et al. (2008b) described that of wairakite. These experiments showed that $P$-induced high-symmetry to low-symmetry phase transitions occur in zeolites of ANA-framework type: leucite has a first-order phase transition from tetragonal to triclinic symmetry $\left(I 4_{1} / a \rightarrow P \overline{1}\right)$ at $\sim 2.4 \mathrm{GPa}$, with a drastic increase in density ( 4.7\%) (Gatta et al., 2008a), pollucite has a cubic-to-triclinic phase transition at $\sim 0.6 \mathrm{GPa}$ $(I a \overline{3} d \rightarrow P \overline{1}$; Gatta et al., 2009a), wairakite shows a phase transition from monoclinic to triclinic $(I 2 / a \rightarrow P \overline{1})$ at $\sim 2.5-2.8 \mathrm{GPa}$ (Ori et al., 2008b). For all the aforementioned isotypic zeolites, the high-to-low symmetry $P$-induced phase transition is completely reversible. For analcime, leucite, pollucite and wairakite, the high- $P$ polymorphs are more compressible than the low- $P$ ones (Table 1).

Gatta et al. (2009a) suggested that there is not a simple relation between the ionic radius of the extra-framework cation and transition pressure in the ANA-framework zeolites; this is because the configuration of the extra-framework species is significantly different [i.e. $\mathrm{NaO}_{4}\left(\mathrm{H}_{2} \mathrm{O}\right)_{2}$-polyhedron in low- $P$ analcime; $\mathrm{KO}_{6}$ in low- $P$ leucite, with the $\mathrm{K}$-sites located at the same positions as the $\mathrm{O}$ atoms of the $\mathrm{H}_{2} \mathrm{O}$ molecules in analcime; $\mathrm{CsO}_{12^{-}}$and $\mathrm{NaO}_{4}\left(\mathrm{H}_{2} \mathrm{O}\right)_{2}$-polyhedron in low- $P$ pollucite; $\mathrm{CaO}_{4}\left(\mathrm{H}_{2} \mathrm{O}\right)_{2}$-polyhedron in low- $P$ wairakite, with a configuration similar to that of analcime]. The different Si/Al-distributions, and hence the general symmetry of the structure, seems to control the transition pressure: analcime and pollucite have the same symmetry (i.e. cubic) with a fully disordered Si/Al-distribution in the framework and both show a phase transition at $P \leqslant 1 \mathrm{GPa}$; leucite is tetragonal with a partial $\mathrm{Si} / \mathrm{Al}$-order in the framework and its transition pressure is $\sim 2.4 \mathrm{GPa}$; wairakite is monoclinic with a highly ordered $\mathrm{Si} / \mathrm{Al}$-distribution and its transition pressure is $\sim 2.5-2.8 \mathrm{GPa}$. Generally, the higher the symmetry, the lower the transition pressure. High symmetry seems to hinder any $P$-induced structural relaxation due to the low degree of freedom. In contrast, low symmetry allows the structure to accommodate the $P$-induced deformation effect with more degrees of freedom.

The observed $\mathrm{H} P$-behaviour of ANA-framework materials corroborates the findings of Sartbaeva et al. $(2006,2008)$ based on geometric simulations. In such a simulation, the bonding constraints in a group of atoms (in this case a tetrahedron) are represented using a template (i.e. the tetrahedron) of holosymmetric shape $(\mathrm{T}-\mathrm{O}$ and $\mathrm{O}-\mathrm{T}-\mathrm{O}$ angles). During the simulation, the template moves and rotates to match the overall position and orientation of the group, while each atom is joined by a constraint to a single vertex of the tetrahedron. Over multiple iterations, the positions of the tetrahedron and its atoms change so as to match each other as closely as possible. This simulation method is particularly suitable for framework silicates, where an important contribution to the dynamics comes from the collective quasi-rigid motion of the tetrahedra (e.g. Wells et al., 2002, 2004; Sartbaeva et al., 2006). The application of this simple modelling technique led the authors to introduce the concept of a "flexibility window". The "flexibility window" is defined as the range of FD in which the tetrahedra retain their holosymmetric shape. The upper and lower limits of the window are defined by steric 


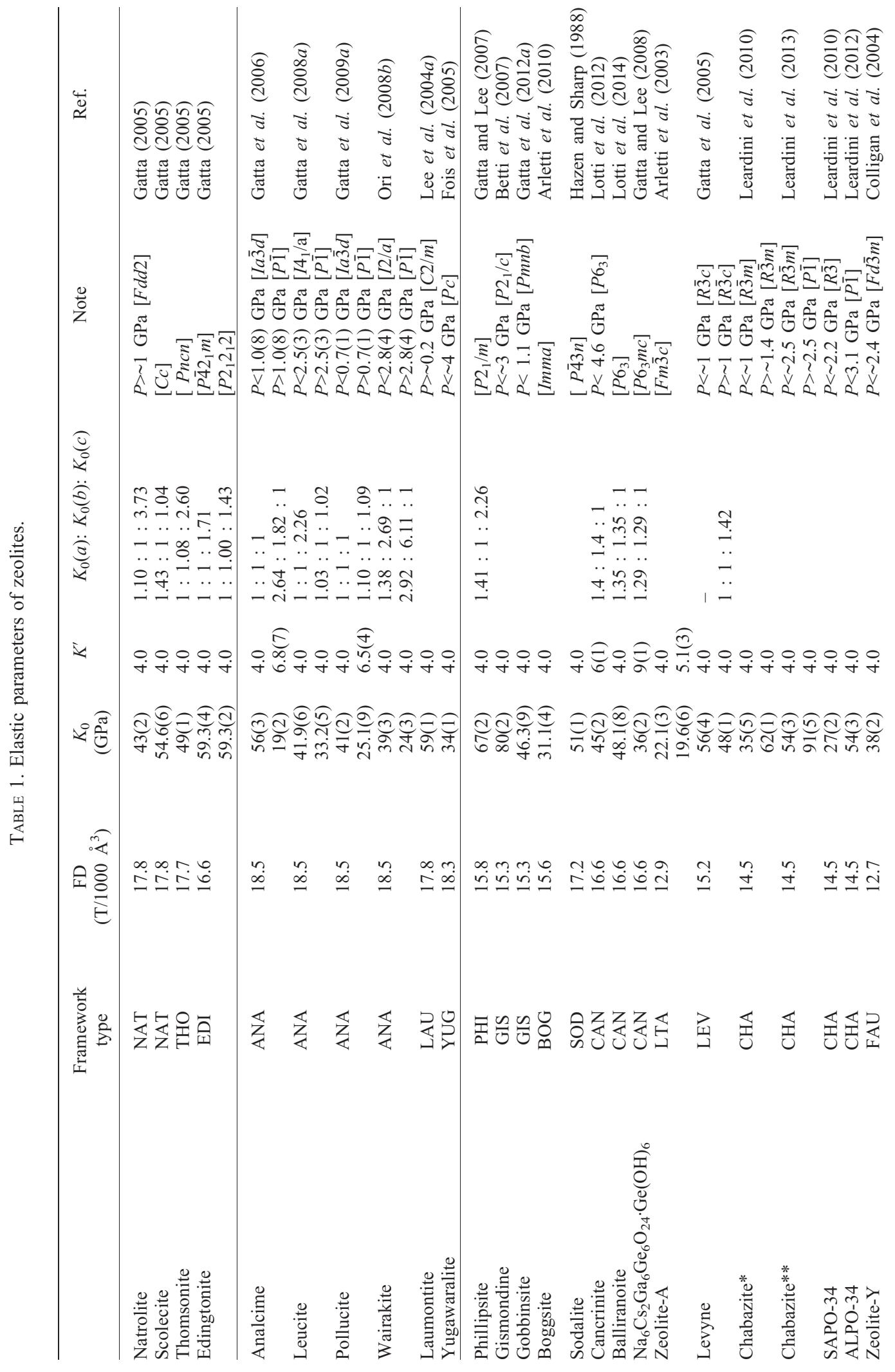


clashes under compression and stretching of bonds upon expansion and depend on the specific geometry and topology of the framework. The "flexibility window" is thus considered as a pervasive property of tetrahedra frameworks. When a structure is forced to deform the tetrahedra in order to accommodate the effects of pressure or temperature, it leaves its "flexibility window" and a phase transition occurs. The $P$-induced transitions observed experimentally for ANA-type minerals show good agreement with the geometric simulations by Sartbaeva et al. (2006, 2008), Gatta et al. (2009b) and Wells et al. (2011).

No zeolites with an ANA framework show evidence of $P$-induced over-hydration effects (through selective sorption of $\mathrm{H}_{2} \mathrm{O}$ molecules from the pressure medium) when compressed in hydrous $P$-fluids, probably due to the small "free diameter" of the voids (e.g. six-membered rings channels along [111]), which are stuffed by the extra-framework species.

Other zeolites with chains of corner-sharing four-membered rings studied at high pressure are laumontite and yugawaralite. The $P$-behaviour of laumontite (ideally $\mathrm{Ca}_{4} \mathrm{Al}_{8} \mathrm{Si}_{16} \mathrm{O}_{48} \cdot n \mathrm{H}_{2} \mathrm{O}$ with $n \leqslant 18$, LAU framework type, 6-2 SBU, Armbruster and Gunter, 2001; Baerlocher et al., 2007) was studied by Lee et al. (2004b) by synchrotron X-ray powder diffraction (XRPD) up to $6.8 \mathrm{GPa}$ using a hydrous $P$-transmitting medium. The authors used a partially dry sample for their experiments, with $12 \mathrm{H}_{2} \mathrm{O}$ molecules per formula unit (m.f.u.). By $P=0.2(1) \mathrm{GPa}$, laumontite has undergone a phase transition to a fully hydrated form (with $18 \mathrm{H}_{2} \mathrm{O}$ m.f.u.) through sorption of extra $\mathrm{H}_{2} \mathrm{O}$ molecules from the $P$-fluid. This led to an expansion of the channels of eight-membered rings, parallel to [100], with a spectacular unit-cell volume increase of $\sim 2.6 \%$. The $P$-induced over-hydrated form maintains the monoclinic $C 2 / m$ symmetry. From 0.2 to $2.4 \mathrm{GPa}$, the over-hydrated laumontite shows a gradual contraction of the unit-cell volume and individual cell edges. At $P>3 \mathrm{GPa}$, the diffraction pattern shows a tripling of the $b$ axis. Lee et al. (2004b) suggested that the observed super-cell transition above $3 \mathrm{GPa}$ might be due to different ordering of the extra-framework species (i.e. $\mathrm{H}_{2} \mathrm{O}$ molecules or $\mathrm{Ca}$ cations inside the channels).

The compressibility of yugawaralite (ideally $\mathrm{Ca}_{2} \mathrm{Al}_{4} \mathrm{Si}_{12} \mathrm{O}_{32} \cdot 8 \mathrm{H}_{2} \mathrm{O}$, YUG framework type, 4 and 8 SBU, Armbruster and Gunter, 2001; 
Baerlocher et al., 2007) was investigated by Fois et al. (2005) by in situ synchrotron powder diffraction up to $11 \mathrm{GPa}$ using a non-penetrating $P$-medium. The crystal structure of this zeolite is characterized by two systems of channels of eight-membered rings along [100] and [001], respectively. The topological symmetry $C 2 / m$ is reduced to $P c$ by $\mathrm{Si} / \mathrm{Al}$ order. Two small discontinuities in the evolution of the unit-cell parameters with $P$ were observed at $1.5-2 \mathrm{GPa}$ and at 4-5 GPa. Fois et al. (2005) simulated the $P$-induced structural evolution of yugawaralite by $a b$ initio molecular dynamics. The main deformation mechanisms, in response to the applied pressure, involve tilting of tetrahedra. These mechanisms seem to be governed by deformation of the Ca-polyhedron: $\mathrm{Ca}-\mathrm{H}_{2} \mathrm{O}$ compression seems to be dominant at low $P$, whereas shortening of Ca-framework $\mathrm{O}$ atoms' distances becomes prevalent at higher $P$.

\section{Group 3: zeolites with chains of edge-sharing four-membered rings}

Only a few 'zeolites with chains of edge-sharing four-membered rings' have so far been investigated at high pressure: phillipsite, gismondine, boggsite and gobbinsite.

Gatta and Lee (2007) described the compressional behaviour and subsequent structure deformation mechanisms of phillipsite (ideally $\mathrm{K}_{2}\left(\mathrm{Ca}_{0.5} \mathrm{Na}\right)_{4} \mathrm{Al}_{6} \mathrm{Si}_{10} \mathrm{O}_{32} \cdot 12 \mathrm{H}_{2} \mathrm{O}$, PHI framework type, 4 and $6 \mathrm{SBU}$, Armbruster and Gunter, 2001; Baerlocher et al., 2007) on the basis of in situ synchrotron powder-diffraction data collected up to $3.64 \mathrm{GPa}$ using a nominally penetrating hydrous $P$-transmitting fluid (i.e. mix methanol: ethanol:water $=16: 3: 1)$. The authors reported significantly anisotropic behaviour of phillipsite within the $P$-range investigated. Despite the use of a hydrous $P$-fluid, no evidence of over-hydration (by sorption of extra $\mathrm{H}_{2} \mathrm{O}$ molecules through the eight-membered ring channels along [100] and along [010]) was observed. The Rietveld structure refinements showed how the structure of phillipsite reacted in response to the applied pressure: cooperative rotation of the tetrahedra increased the ellipticity of the channel systems, maintaining the original elliptical configuration (i.e. without any 'inversion' in ellipticity). Gismondine (ideally $\mathrm{Ca}_{4} \mathrm{Al}_{8} \mathrm{Si}_{8} \mathrm{O}_{32} \cdot 16 \mathrm{H}_{2} \mathrm{O}$, GIS framework type, 4 and 6 SBU, Armbruster and Gunter, 2001; Baerlocher et al., 2007) is the most studied zeolite at high pressure belonging to Group 3. The $\mathrm{H} P$-behaviour of gismondine was investigated by in situ synchrotron powder-diffraction using a non-penetrating $P$-medium (i.e. silicon-oil, Betti et al., 2007 ) and a penetrating hydrous $P$-fluid (i.e. mix methanol:ethanol:water $=16: 3: 1$, Ori et al., 2008a) up to $10 \mathrm{GPa}$ and simulated by ab initio moleculardynamics calculations. Using the non-penetrating $P$-fluid, at $P>7.4 \mathrm{GPa}$, the diffraction patterns show subsidiary peaks, incompatible with the unit cell and the symmetry $\left(P 2_{1} / c\right)$ of gismondine. The $P$-induced structural evolution was simulated by $a b$ initio molecular-dynamics calculations using the experimental unit-cell parameters at different pressures. Ab initio modelling showed that the main deformation mechanisms act on the fourmembered rings (that form the mutually-interpenetrating double crankshaft chains) and, as a consequence, the two channels of eight-membered rings along [100] and [010] become more elliptic with $P$. When the hydrous medium is used as $P$-fluid, over-hydration was observed at very low pressure through the increase of the site-occupancy factor of the existing (and partly occupied) $\mathrm{H}_{2} \mathrm{O}$ sites. Over-hydration leads to a slightly different elastic behaviour and structure evolution with respect to gismondine compressed in a nonpenetrating medium. The two experiments on gismondine by Betti et al. (2007) and Ori et al. (2008a) showed (unexpectedly) very low compressibilities for an open-framework material. Lee et al. (2008) and Jang et al. (2010) studied the $P$-behaviour of two synthetic analogues with GIS topology, both compressed in a penetrating hydrous fluid: K-gallosilicate (K-GaSi-GIS) and K-aluminogermanate (K-AlGe-GIS), respectively. $\mathrm{K}-\mathrm{GaSi}$-GIS has an early $P$-induced over-hydration, coupled with a change of compressional behaviour and a resulting disordering of the extraframework species. In contrast, K-AlGe-GIS shows a linear unit-cell-volume compression within the $P$-range investigated, with no evidence of over-hydration. On the whole, K-AlGe-GIS is more compressible than K-GaSi-GIS and both of the synthetic gismondines are, in turn, significantly more compressible than gismondine itself. If we compare the experimental findings on natural and synthetic gismondines, it seems that there is a different response to hydrostatic pressure in isotypic materials (i.e. sharing the same GIS topology) with different framework or extraframework species.

Arletti et al. (2010) reported the results of an in situ high-pressure synchrotron powder-diffraction investigation on boggsite (ideally 
$\mathrm{Ca}_{8} \mathrm{Na}_{3} \mathrm{Al}_{19} \mathrm{Si}_{77} \mathrm{O}_{192} \cdot 70 \mathrm{H}_{2} \mathrm{O}$, BOG framework type, 4 and $6 \mathrm{SBU}$, Armbruster and Gunter, 2001; Baerlocher et al., 2007), using both penetrating ( $\mathrm{mix}$ methanol:ethanol:water $=$ 16:3:1, up to $7.6 \mathrm{GPa}$ ) and non-penetrating (i.e. silicon oil, up to $5.9 \mathrm{GPa}) P$-fluids. The Rietveld structural refinements at high pressure show the penetration of 13 additional $\mathrm{H}_{2} \mathrm{O}$ molecules, between 0.3 and $2.9 \mathrm{GPa}$, where the hydrous $P$-fluid is used. This over-hydration does not lead to unit-cell-volume expansion, as it arises from an increase in the occupancy factor at already existing $\mathrm{H}_{2} \mathrm{O}$ sites (i.e. without the need for any new extra-framework sites). The compressibility of boggsite is higher when compressed in a nonpenetrating $P$-fluid.

Gatta et al. (2012a) recently described the elastic behaviour and $P$-induced structure evolution of gobbinsite (ideal formula between $\mathrm{Na}_{5} \mathrm{Al}_{5}$ $\mathrm{Si}_{11} \mathrm{O}_{32} \cdot 11 \mathrm{H}_{2} \mathrm{O}$ and $\mathrm{Na}_{4} \mathrm{CaAl}_{6} \mathrm{Si}_{10} \mathrm{O}_{32} \cdot 11 \mathrm{H}_{2} \mathrm{O}$, GIS framework type, 4 and $6 \mathrm{SBU}$, Armbruster and Gunter, 2001; Baerlocher et al., 2007) by in situ single-crystal XRD up to $4.3 \mathrm{GPa}$ with a diamond-anvil cell and using a non-penetrating $P$ transmitting medium. The elastic behaviour of this zeolite is unusual, with two changes in compressibility: the first at $1.1-1.3 \mathrm{GPa}$ and the second at 2.7-3.2 GPa. The unit-cell compression is significantly anisotropic. A series of structure refinements show that, in response to the applied pressure, the channel of eight-membered rings parallel to [100] significantly increases its ellipticity, whereas the channel parallel to [010] contracts and becomes more circular at $P>1.3$ GPa. The first change of elastic behaviour (at $1.1-1.3 \mathrm{GPa}$ ) reflects a partial re-organization of the $\mathrm{H}_{2} \mathrm{O}$ sites and the second change (at 2.7-3.2 $\mathrm{GPa}$ ) seems to be governed by new frameworkdeformational modes, along with a change in the coordination environment of the channel cations.

\section{Group 4: zeolites with six-membered rings}

Many zeolites belonging to the group 'with sixmembered rings' have been studied at high pressure: sodalite, cancrinite, zeolite Na-A, levyne, chabazite, zeolite $\mathrm{Y}\left(\mathrm{SiO}_{2}\right.$-faujasite $)$ and RHO-zeolite ( $\mathrm{SiO}_{2}$-pahasapaite). Microporous minerals with sodalite- and cancrinite-type structures are not considered zeolites, according to Coombs et al. (1997), but rather as "feldspathoids". However, we prefer a broader view here as the crystal structures of these microporous materials show several zeolitic features.
The framework of sodalites (ideally $\mathrm{Na}_{8} \mathrm{Cl}_{2} \mathrm{Al}_{6} \mathrm{Si}_{6} \mathrm{O}_{24}$, SOD framework type, 6-2 SBU, Baerlocher et al., 2007) is built of sixmembered rings. The unique polymerization of six-membered rings and four-membered rings form truncated octahedral cages, well known as 'sodalite cages'. The topological symmetry of the SOD framework is $\operatorname{Im} 3 \mathrm{~m}$. In sodalites, the extraframework content is represented by tetrahedral clusters (e.g. $\left[\mathrm{Na}_{4} \mathrm{Cl}\right]^{3+}$ ) that lie in the centre of the cage. The real symmetry of sodalite-like structures (such as nosean $\mathrm{Na}_{8} \mathrm{Al}_{6} \mathrm{Si}_{6} \mathrm{O}_{24} \mathrm{SO}_{4}$, hauyne $\mathrm{Na}_{5} \mathrm{Ca}_{2} \mathrm{Al}_{6} \mathrm{Si}_{6} \mathrm{O}_{24}\left(\mathrm{SO}_{4}\right)_{1.5}$, danalite $\mathrm{Fe}_{8} \mathrm{Be}_{6} \mathrm{Si}_{6} \mathrm{O}_{24} \mathrm{~S}_{2}$ and helvite $\left.\mathrm{Mn}_{8} \mathrm{Be}_{6} \mathrm{Si}_{6} \mathrm{O}_{24} \mathrm{~S}_{2}\right)$ is reduced (often to $P \overline{4} 3 n$ ) due to ordering of $\mathrm{Si} / \mathrm{Al}$ or Be/Si. Hazen and Sharp (1988) reported the compressional behaviour of a sodalite up to 2.6 GPa, by single-crystal XRD using a (nominally) non-penetrating $P$-medium. No discontinuities in $P-V$ plot were observed within the $P$-range investigated and the material retained its cubic symmetry. However, the authors noted that the sodalite crystal deteriorated irreversibly at $P$ $>3.0 \mathrm{GPa}$. On the basis of their experimental findings, Hazen and Sharp (1988) did not exclude that sodalite experienced a reconstructive transition to an unknown $\mathrm{H} P$-polymorph. No $\mathrm{H} P$ structural refinement of sodalite was undertaken within the $P$-range investigated. Later, Werner et al. (1996) examined both natural and synthetic sodalites at high pressure by single-crystal diffraction up to $7.4 \mathrm{GPa}$ using non-penetrating $P$-media. Evidence of a change in compressibility at about $3 \mathrm{GPa}$ was reported, though the evolution of the structural parameters (e.g. intra- and intertetrahedral angles, rotation of the tetrahedra with respect to the four-fold axis, $\mathrm{Na}-\mathrm{Cl}$ distance) do not show any significant change with $P$ and the diffraction conditions suggested that the symmetry at room conditions is maintained within the $P$-range investigated. Synthetic $\mathrm{SiO}_{2}-$ sodalites with organic template molecules have also been studied at $\mathrm{H} P$-conditions (Fütterer et al., 1994; Knorr et al., 2000).

Lotti et al. (2012, 2014) investigated the $P$-behaviour of cancrinite $\left(\mathrm{Na}_{6.59} \mathrm{Ca}_{0.93}\right.$ $\left.\left(\mathrm{Si}_{6} \mathrm{Al}_{6} \mathrm{O}_{24}\right)\left(\mathrm{CO}_{3}\right)_{1.04} \mathrm{~F}_{0.41} \cdot 2 \mathrm{H}_{2} \mathrm{O}\right)$ and balliranoite $\left(\mathrm{Na}_{4.47} \mathrm{Ca}_{2.86} \mathrm{~K}_{0.11}\left(\mathrm{Si}_{5.96} \mathrm{Al}_{6.04} \mathrm{O}_{24}\right) \mathrm{Cl}_{2.03}\right.$ $\left.\left(\mathrm{CO}_{3}\right)_{0.78}\left(\mathrm{SO}_{4}\right)_{0.33}\right)$ by in situ single-crystal XRD using a non-penetrating $P$-fluid up to $6-7 \mathrm{GPa}$. These minerals share the CAN-topology of the framework (Baerlocher et al., 2007). The framework consists of layers containing single sixmembered rings of tetrahedra (i.e. non- 
interconnected within the layers) in stacking sequences, which give rise to various framework topologies: the simplest sequence $-\mathrm{ABAB}$ - results in the CAN framework. Each single sixmembered ring within the layers is perpendicular to [0001] and links to three rings in the previous layer and three rings in the next layer, forming columns of base-sharing cancrinite cages (also called 'undecahedral cages', 'can units' or ' $4{ }^{6} 6^{5}$ units'). These columns surround iso-oriented channels of 12-membered rings parallel to [0001]. Cancrinite and balliranoite have a perfectly ordered $\mathrm{Al} / \mathrm{Si}$-distribution and their general symmetry is $P 6_{3}$. The main difference between these two minerals is in the extraframework content, in particular in the cage content: (1) in cancrinite, alternating $\mathrm{Na}-\mathrm{H}_{2} \mathrm{O}$ clusters give rise to chains of non-equally spaced $\mathrm{Na}-\mathrm{H}_{2} \mathrm{O} \cdots \mathrm{Na}-\mathrm{H}_{2} \mathrm{O}$; (2) in balliranoite, chains of almost equally spaced $-\mathrm{Ca}-\mathrm{Cl}-\mathrm{Ca}-\mathrm{Cl}-$ occur. The channels of 12-membered rings are occupied by alkali and alkaline-earth cations $\left(\mathrm{Na}^{+}, \mathrm{K}^{+}\right.$, $\left.\mathrm{Ca}^{2+}\right)$ close to the walls and various anion $\left(\mathrm{CO}_{3}^{2-}\right.$, $\mathrm{SO}_{4}^{2-}$ ) and/or molecular groups near the centre.

Cancrinite has a subtle change of compressional behaviour at 4.6-5.0 GPa (Lotti et al., 2012), though no variation in the monotonic evolution of the structure parameters (e.g. bond distances and angle) was observed. Balliranoite shows no evidence of a phase transition, structure collapse or change in its compressional behaviour within the $P$-range investigated (Lotti et al., 2014). The volume compressibility of cancrinite and balliranoite are similar (they differ by less than $2 \sigma$ ) and they both show a modest elastic anisotropy (20-35\%) with the most compressible direction (\|[0001]) perpendicular to the stacking plane of the hexagonal layers $(\|(0001))$. The two minerals are less compressible than the synthetic isotypic $\mathrm{Na}_{6} \mathrm{Cs}_{2} \mathrm{Ga}_{6} \mathrm{Ge}_{6} \mathrm{O}_{24} \cdot\left(\mathrm{Ge}(\mathrm{OH})_{6}\right)$, studied at high pressure by Gatta and Lee (2008). For both cancrinite and balliranoite, the $\mathrm{H} P$-structure refinements allow the main deformation mechanisms to be described: acting via tilting of tetrahedra, that is responsible for the anisotropic compression on (0001) and along [0001].

Synthetic zeolite Na-A $\left(\mathrm{Na}_{12} \mathrm{Al}_{12} \mathrm{Si}_{12} \mathrm{O}_{48}\right.$ $\cdot 26 \mathrm{H}_{2} \mathrm{O}$, LTA framework type, 6-2 SBU, Baerlocher et al., 2007) is probably one of the most studied zeolites at high pressure and we can ascribe the first reported case of over-hydration to this zeolite. Its framework shows strong structural homologies with that of sodalite. The elastic behaviour of this zeolite was first studied by
Hazen (1983) and Hazen and Finger (1984) by in situ single-crystal diffraction up to $4 \mathrm{GPa}$ using both penetrating and non-penetrating $P$-media. The authors observed a significantly different compressional behaviour of this zeolite in response to the molecular size of the $P$-transmitting medium: the compressibility was higher when non-penetrating $P$-media were used. Though not fully understood because of the lack of structure refinements at high pressure, the different compressibility of zeolite Na-A was ascribed to a potential interaction between zeolite and $P$-fluids. The $P$-induced penetration of extra molecules, through zeolitic cavities, has possibly made the structure less compressible when compared to the results of experiments performed using non-penetrating $P$-fluids. The elastic behaviour of zeolite Na-A was reinvestigated by Arletti et al. (2003) by synchrotron powder diffraction up to $6.8 \mathrm{GPa}$ using a non-penetrating $P$-medium. No phase transition was observed within the $P$-range investigated, confirming the experimental findings of Hazen (1983) and Hazen and Finger (1984). A more recent experiment on synthetic zeolite $\mathrm{Na}-\mathrm{A}$ was undertaken by Likhacheva et al. (2009) by in situ synchrotron XRPD up to $2.5 \mathrm{GPa}$ using pure $\mathrm{H}_{2} \mathrm{O}$ as the $P$-medium in a diamond-anvil cell. Rietveld refinement at $0.37 \mathrm{GPa}$ provided evidence of over-hydration, with a significant increase $(30 \%)$ of the total $\mathrm{H}_{2} \mathrm{O}$ content. The over-hydrated state of the zeolite was partly preserved after pressure release.

Levyne [ideally $\left(\mathrm{Ca}_{0.5}, \mathrm{Na}, \mathrm{K}\right)_{6} \mathrm{Al}_{6} \mathrm{Si}_{12} \mathrm{O}_{36}$ $\cdot 18 \mathrm{H}_{2} \mathrm{O}$, LEV framework type, $6 \mathrm{SBU}$, Armbruster and Gunter, 2001; Berlocher et al., 2007] is another member of Group 4 studied at high pressure. Its elastic behaviour and $P$-induced structural evolution were investigated by Gatta $e t$ al. (2005), using a natural sample, by in situ single-crystal XRD up to $\sim 5 \mathrm{GPa}$, using a nonpenetrating $P$-medium. Levyne (rhombohedral, with $R \overline{3} m$ space group) shows peculiar elastic behaviour in the low- $P$ regime (i.e. $P<1 \mathrm{GPa}$ ): the $c$ axis decreases between $0-0.2 \mathrm{GPa}$, then increases up to $0.6-0.8 \mathrm{GPa}$ and above this $P, c$ decreases as expected; the $a$ parameter first increases up to $0.2 \mathrm{GPa}$, then at $P>0.2 \mathrm{GPa}$ decreases as expected. Surprisingly, these anomalous lattice variations have only a minor effect on the behaviour of the cell volume and do not imply any change in the symmetry of this zeolite. The structural refinements carried out at different pressures allowed us to interpret the reasons for 
the anomalous elastic behaviour of this zeolite, highlighting two distinct deformation mechanisms for the framework: the first (predominant at $P$ $<1 \mathrm{GPa}$ ) is governed by cooperative rotation of the tetrahedra belonging to the six-membered double rings and the second (at $P>1 \mathrm{GPa}$ ) is governed by compression of the 'joint-unit' between the six-membered rings (Fig. 3). The $P$-induced deformation mechanisms, deduced on the basis of a modest number of structure refinements, are well reproduced by geometric simulation (Gatta and Wells, 2006) based on a 'rigid-unit mode' approach and using the experimental unit-cell parameters previously published (Gatta et al., 2005).

A series of experiments at high pressure were carried out on chabazite (ideally $\left(\mathrm{Ca}_{0.5}, \mathrm{Na}, \mathrm{K}\right)_{4}$ $\mathrm{Al}_{4} \mathrm{Si}_{8} \mathrm{O}_{24} \cdot 12 \mathrm{H}_{2} \mathrm{O}$, CHA framework type, $6 \mathrm{SBU}$, Armbruster and Gunter, 2001; Baerlocher et al., 2007) and its synthetic analogues (i.e. aluminophosphate ALPO-34, silicoaluminophosphate SAPO-34) by Leardini et al. (2010, 2012, 2013). All the experiments were performed by in situ synchrotron powder-diffraction using a nonpenetrating $P$-fluid (i.e. silicon oil), up to 5-7 GPa. The experiments on chabazites with different compositions (i.e. $\left(\mathrm{K}_{1.36} \mathrm{Ca}_{1.04} \mathrm{Sr}_{0.40}\right.$ $\left.\mathrm{Na}_{0.28} \mathrm{Ba}_{0.06} \mathrm{Mg}_{0.02}\right) \mathrm{Si}_{7.17} \mathrm{Al}_{4.87} \mathrm{O}_{24} \cdot 13.16 \mathrm{H}_{2} \mathrm{O}$ in Leardini et al. 2010, $\left(\mathrm{Ca}_{1.32} \mathrm{~K}_{0.45} \mathrm{Na}_{0.13} \mathrm{Sr}_{0.10}\right)$ $\mathrm{Si}_{8.55} \mathrm{Al}_{3.45} \mathrm{O}_{24} \cdot 11.30 \mathrm{H}_{2} \mathrm{O}$ in Leardini et al. 2013) showed: (1) a change in the elastic behaviour (at 1-1.4 GPa) for the K-rich sample, not described as a phase transition, with a decrease in compressibility at high pressure; (2) a $P$-induced first-order phase transition for the $\mathrm{Ca}-$ rich sample at $2.1 \mathrm{GPa}$, from rhombohedral $(R \overline{3} \mathrm{~m})$ to triclinic $(P \overline{1}$, pseudo-rhombohedral) symmetry, with a drastic decrease in compressibility for the $\mathrm{H} P$-polymorph. The change in compressional behaviour observed for the K-rich chabazite seems to be governed by similar mechanisms to those previously observed in levyne (Gatta et al., 2005). The first-order phase transition observed for the Ca-rich sample is expected to be displacive in character. The $P$-induced effects in both $\mathrm{K}$ - and Ca-rich chabazite are completely reversible. The different behaviour of the $\mathrm{K}$ - and Ca-rich chabazite in response to the applied pressure was ascribed to the different nature (and bonding configuration) of the extra-framework constituents. The important role played by the extraframework configuration on the compressional behaviour of this group of isotypic materials is also corroborated by the experimental findings on SAPO-34. In SAPO-34, the pores are partly filled by morpholine (as an organic template) and $\mathrm{H}_{2} \mathrm{O}$ molecules, forming molecular complexes. Under hydrostatic pressure, SAPO-34 is significantly more compressible than chabazites and its compressional behaviour follows a monotonic trend within the $P$-range investigated. On the other hand, AlPO-34 is stiffer than chabazites and SAPO-34, probably due to the octahedral coordination of part of its framework Al. In this
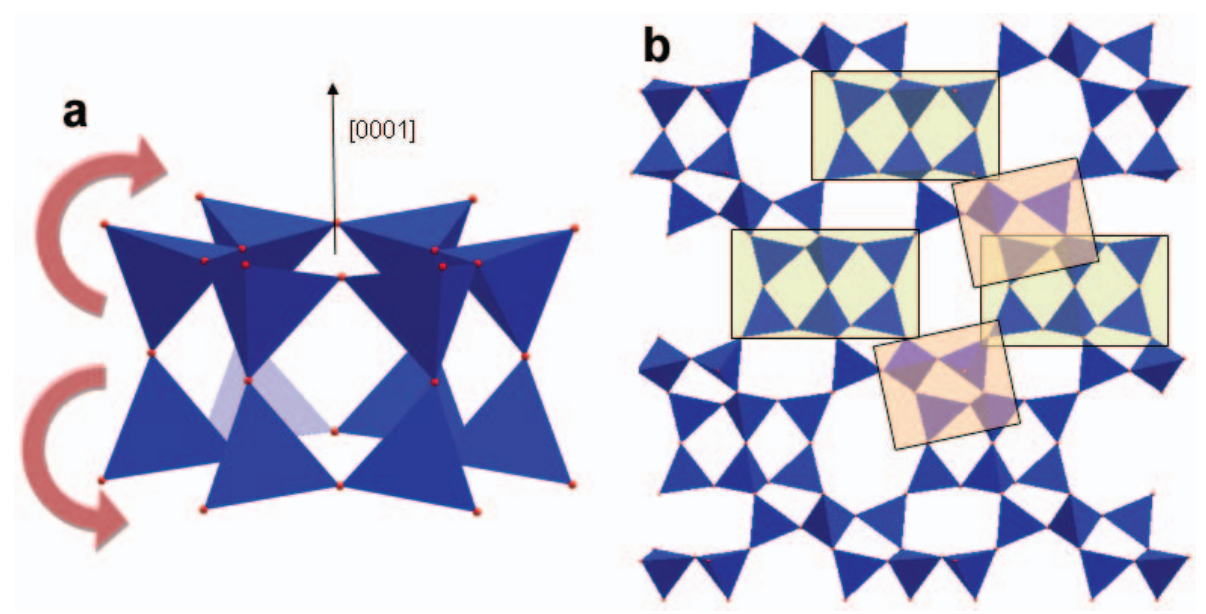

FIG. 3. (a) Double six-membered ring-unit in the levyne framework and the $P$-induced mechanism at $P<0.8 \mathrm{GPa}$, which leads to an expansion of the framework along [0001]. (b) LEV framework; the double six-membered rings are highlightened in green rectangles and the 'joint-units' in orange rectangles. 
light, direct comparison between AlPO-34 and chabazite and SAPO-34 does not have a robust physical basis.

The purely siliceous zeolite Y (FAU framework type, 6 and 4 SBU, Baerlocher et al., 2007) was studied at high pressure by Colligan et al. (2004) by in situ synchrotron XRPD using penetrating and non-penetrating $P$-fluids. Siliceous $\mathrm{Y}$ is the synthetic counterpart of faujasite (ideally $\mathrm{Na}_{20} \mathrm{Ca}_{12} \mathrm{Mg}_{8} \mathrm{Al}_{60} \mathrm{Si}_{132} \mathrm{O}_{384} \cdot 235 \mathrm{H}_{2} \mathrm{O}$, Armbruster and Gunter, 2001); its framework involves silicate tetrahedra and hence the resulting pores are empty and hydrophobic. When a non-penetrating medium was used, the diffraction pattern showed a loss of long-range order at $P$ $>2.4 \mathrm{GPa}$. In contrast, when a hydrous penetrating $P$-fluid was used, two distinct compressibility regions were observed (i.e. below and above $4 \mathrm{GPa})$. The authors provided Rietveld structure models of zeolite $\mathrm{Y}$ at different pressures and described sequential pore-filling (either by $\mathrm{H}_{2} \mathrm{O}$ or methanol) at low pressure, followed by framework deformation at high pressure.

A further high- $P$ study on synthetic faujasite with composition $\mathrm{Na}_{86} \mathrm{Si}_{106} \mathrm{Al}_{86} \mathrm{O}_{384} \cdot 175 \mathrm{H}_{2} \mathrm{O}$ was undertaken by Isambert et al. (2008), using in situ XRPD and Raman spectroscopy. The aim of the experiments was to study the $P$-induced amorphization process of faujasite. No $P$-fluid was used. The authors observed two changes in the compressional behaviour at 2 and $3.5 \mathrm{GPa}$ and amorphization was not complete by $12 \mathrm{GPa}$. Structure refinements were not carried out. The scattering in the evolution of the unit-cell parameters vs. $P$ does not allow a unique interpretation of the observed phenomena. We cannot exclude the possibility that the nonhydrostatic conditions of the experiment played an important role in the $P$-behaviour of the zeolite, making comparison with the other experiments on faujasite difficult.

A series of high-pressure experiments were carried out by Lee et al. (2001) on the synthetic zeolites Li-, (Na,Cs)- and Cd-RHO $\left[(\mathrm{Li}, \mathrm{Na}, \mathrm{Cs})_{12}\left(\mathrm{Al}_{12} \mathrm{Si}_{36} \mathrm{O}_{96}\right) \cdot 44 \mathrm{H}_{2} \mathrm{O}\right.$, RHO framework type, 8 and 6 and 4 SBU, Baerlocher et al., 2007] by in situ synchrotron powder-diffraction up to $3 \mathrm{GPa}$, using a hydrous penetrating $P$-transmitting fluid. Zeolite RHO is the synthetic counterpart of pahasapaite (ideally $\mathrm{Li}_{8}(\mathrm{Ca}, \mathrm{Li}, \mathrm{K}, \mathrm{Na})_{11} \mathrm{Be}_{24}\left(\mathrm{PO}_{4}\right)_{24} \cdot 38 \mathrm{H}_{2} \mathrm{O}$, Armbruster and Gunter, 2001). The high-pressure experiments of Lee et al. (2001) showed a transformation from centric $\operatorname{Im} \overline{3} m$ to acentric
$I \overline{4} 3 \mathrm{~m}$ at low pressure $(P<0.5 \mathrm{GPa})$. The large channels in the exchanged RHO-zeolites allowed $P$-induced penetration of $\mathrm{H}_{2} \mathrm{O}$ molecules belonging to the $P$-medium, showing cationspecific $P$-responses dictated by complex sorption kinetics and mechanisms of the penetrating molecules.

\section{Group 5: zeolites of the mordenite group}

Mordenite and bikitaite are two zeolites belonging to the 'mordenite group' that have been studied at high pressure. Gatta and Lee (2006) investigated the compressional behaviour of synthetic mordenite $\left(\mathrm{Na}_{6} \mathrm{Al}_{6} \mathrm{Si}_{42} \mathrm{O}_{96} \cdot 19 \mathrm{H}_{2} \mathrm{O}\right.$, MOR framework type, 5-1 SBU, Armbruster and Gunter, 2001; Baerlocher et al., 2007) by in situ synchrotron powder diffraction up to $5.7 \mathrm{GPa}$, using a nominally penetrating hydrous $P$-fluid. The quality of the data allowed only the refinement of unit-cell parameters by fullprofile fit. The evolution of the unit-cell parameters with $P$ gave no evidence of overhydration. However, the lack of structure refinements prevented unambiguous descriptions of the $P$-phenomena at the atomic level. Mordenite is significantly anisotropic and the reasons for this were intuitively assumed by Gatta and Lee (2006) on the basis of the geometrical configuration of the three systems of channels in the mordenite framework.

Bikitaite is a rare Li-bearing zeolite [ideally $\mathrm{Li}_{2}\left(\mathrm{Al}_{2} \mathrm{Si}_{4} \mathrm{O}_{12}\right) \cdot 2 \mathrm{H}_{2} \mathrm{O}$, BIK framework type, 5-1 SBU, Armbruster and Gunter, 2001; Baerlocher et al., 2007]. The $P$-behaviour of this zeolite was investigated mainly for an unusual structural aspect: the presence of a 'floating' one-dimensional $\mathrm{H}_{2} \mathrm{O}$ chain ('mono-dimensional ice') along the channel of eight-membered rings parallel to [010] (Fois et al., 1999). The compressional behaviour and the $P$-induced structure evolution of bikitaite were also investigated by Comodi et al. (2003) using in situ single-crystal diffraction up to $4 \mathrm{GPa}$ and by Ferro et al. (2002) using synchrotron powder-diffraction up to $10 \mathrm{GPa}$ and $a b$ initio molecular-dynamics simulations. A 'compression' of the $\mathrm{H}_{2} \mathrm{O}$-chains was experimentally observed by Comodi et al. (2003) between 0 and $4 \mathrm{GPa}$. Ferro et al. (2002) showed that, at $P>4 \mathrm{GPa}$, tetrahedral tilting induces a close approach of framework $\mathrm{O}$ atoms toward $\mathrm{H}_{2} \mathrm{O}$ molecules, suggesting the formation of host-guest hydrogen bonds, while still preserving the onedimensional chain. 
Group 6: zeolites of the heulandite group (or zeolites with $\mathrm{T}_{10} \mathrm{O}_{20}$ units)

Heulandite [ideally $(\mathrm{Na}, \mathrm{K}) \mathrm{Ca}_{4}\left(\mathrm{Al}_{9} \mathrm{Si}_{27} \mathrm{O}_{72}\right)$ $\cdot 24 \mathrm{H}_{2} \mathrm{O}$, HEU framework type, 4-4=1 SBU, Armbruster and Gunter, 2001; Baerlocher et al., 2007] is the only member of the 'heulandite group', or 'zeolites with $\mathrm{T}_{10} \mathrm{O}_{20}$ units', studied at high pressure. Comodi et al. (2001) described the compressional behaviour and $P$-induced structural evolution of heulandite up to $\sim 4 \mathrm{GPa}$, using in situ single-crystal diffraction with a diamond-anvil cell and a non-penetrating $P$-fluid (i.e. glycerol). No phase transition (or change in the compressional behaviour) was observed within the $P$-range investigated. Structure refinements at different pressures allowed Comodi et al. (2001) and Gatta et al. (2003) to describe the main deformation mechanisms at the atomic level: the compression of the heulandite structure is the result of the interplay between the 'soft' behaviour of the three channel systems (i.e. channels of ten- and eight-membered rings along [001], channels of eight-membered rings along [100]) and the 'rigid' behaviour of the secondary building unit (i.e. $4-4=1$ SBU or $\mathrm{T}_{10} \mathrm{O}_{20}$ units). The SBU form chains which tilt with applied pressure and configuration of the extra-framework species was maintained within the $P$-range investigated.

\section{Other rare zeolites}

There are a few examples of zeolites, extremely rare or absent in Nature, that do not belong to the aforementioned groups and have been studied at high- $P$ : mutinaite (and its synthetic counterpart 'silicalite' ZSM-5) and the synthetic ABW-type zeolites.

Mutinaite $\left(\left(\mathrm{Na}_{2.76} \mathrm{~K}_{0.11} \mathrm{Mg}_{0.21} \mathrm{Ca}_{3.78}\right)\right.$ $\left(\mathrm{Al}_{11.20} \mathrm{Si}_{84.91} \mathrm{O}_{192}\right) \cdot 60 \mathrm{H}_{2} \mathrm{O}$, MFI framework type, 5-1 SBU, Armbruster and Gunter, 2001; Baerlocher et al., 2007), is a rare zeolite from Antarctica (Galli et al., 1997; Vezzalini et al., 1997). Its crystal structure consists of chains of five-membered rings (the so called "pentasil chains") and channels of 10-membered rings parallel to [100] and [010]. The structure refinement of mutinaite suggested a disordered $\mathrm{Si} / \mathrm{Al}$-distribution in the framework, along with a complex disordered cation $/ \mathrm{H}_{2} \mathrm{O}$ distribution at the extra-framework sites. A series of $\mathrm{H} P$-experiments have been carried out using synchrotron powder-diffraction on mutinaite
$\left(\left(\mathrm{Na}_{2.76} \mathrm{~K}_{0.11} \mathrm{Mg}_{0.21} \mathrm{Ca}_{3.78}\right)\left(\mathrm{Al}_{11.20} \mathrm{Si}_{84.91} \mathrm{O}_{192}\right)\right.$ $\cdot 60 \mathrm{H}_{2} \mathrm{O}$, sp. gr. Pnma, Quartieri et al., 2012, compressed in a non-penetrating $P$-fluid), pure silicalite (i.e. $\mathrm{Si}_{96} \mathrm{O}_{196} \cdot 2.5 \mathrm{H}_{2} \mathrm{O}$ and $\mathrm{Si}_{96} \mathrm{O}_{196} \cdot 3 \mathrm{H}_{2} \mathrm{O}, P 2_{1} / n$, Quartieri et al., 2012, compressed in a non-penetrating $P$-fluid), NaZSM-5 (i.e. $\left(\mathrm{Na}_{4.58} \mathrm{~K}_{0.02}\right)\left(\mathrm{Ca}_{0.18} \mathrm{Mg}_{0.03} \mathrm{Ba}_{0.01}\right.$ $\left.\mathrm{Fe}_{0.05} \mathrm{Sr}_{0.01}\right)\left(\mathrm{Al}_{4.48} \mathrm{Si}_{91.35}\right) \mathrm{O}_{192} \cdot 28.39 \mathrm{H}_{2} \mathrm{O}$, Pnma, Arletti et al., 2011, using penetrating and nonpenetrating $P$-fluids) and H-ZSM-5 $\left(\left(\mathrm{H}_{6.8} \mathrm{Na}_{1.1}\right)\left(\mathrm{Al}_{7.9} \mathrm{Si}_{89.8}\right) \mathrm{O}_{192} \cdot 36 \mathrm{H}_{2} \mathrm{O}\right.$, Pnma, Quartieri et al., 2011, using penetrating and non-penetrating $P$-fluids). Mutinaite showed monotonic compressional behaviour within the $P$-range investigated (i.e. $0-6 \mathrm{GPa}$ ). Silicalites, $\mathrm{Si}_{96} \mathrm{O}_{196} \cdot 2.5 \mathrm{H}_{2} \mathrm{O}$ and $\mathrm{Si}_{96} \mathrm{O}_{196} \cdot 3 \mathrm{H}_{2} \mathrm{O}$, had an irreversible phase transition from monoclinic $\left(P 2_{1} / n\right)$ to orthorhombic (Pnma) symmetry at $\sim 1 \mathrm{GPa}$. Na-ZSM-5 and H-ZSM-5 showed different behaviour in response to the nature of the $P$-fluid, with a $P$-induced penetration of extra $\mathrm{H}_{2} \mathrm{O}$ molecules (or alcohol molecules) from the hydrous $P$-medium (i.e. methanol:ethanol:water $=$ 16:3:1), though without any $P$-induced volume expansion. In Na-ZSM-5, over-hydration seems to be partly reversible (i.e. some of the extraframework molecules remain in the channels on decompression). In addition, $P$-induced overhydration in Na-ZSM-5 and H-ZSM-5 made the materials less compressible than in non-penetrating $P$-fluids.

Pure silicalite was also used as a $\mathrm{Si}_{n} \mathrm{O}_{2 n}$ target material to study $P$-induced amorphization processes, by in situ Raman spectroscopy, XRPD and reverse Monte Carlo modelling (Haines et al., 2009). Haines et al. (2010) showed that the $P$-induced penetration of extra molecules ( $\mathrm{Ar}$ and $\mathrm{CO}_{2}$ ) in silicalite hinders structure collapse and hence the $P$-induced amorphization.

ABW-type zeolites are synthetic compounds (ABW framework type, 4-4 SBU, Baerlocher et $a l ., 2007)$ and no natural analogues have so far been found. The type material is Li-ABW (i.e. $\mathrm{LiAlSiO}_{4} \cdot \mathrm{H}_{2} \mathrm{O}$ ), but a series of isotypic compounds has been synthesized (Baur and Fischer, 2000; Kahlenberg et al., 2001). The crystal structure of $\mathrm{LiAlSiO}_{4} \cdot \mathrm{H}_{2} \mathrm{O}$ is orthorhombic, $P n a 2_{1}$ with lattice parameters: $a \approx$ $10.3, b \approx 8.2, c \approx 4.9 \AA$ and contains distorted channels of eight-membered rings along [001], that contain the extra-framework species. A fully ordered $\mathrm{Si} / \mathrm{Al}$-distribution in the framework was observed. The extra-framework 
species consists of one independent cation site $\left(\mathrm{Li}^{+}\right)$, lying off-centre in channels, along with one independent $\mathrm{H}_{2} \mathrm{O}$ site. The Li-site has fourcoordination, as observed also in other Li-bearing zeolites (e.g. bikitaite, Gatta et al., 2003). In particular, the coordination of $\mathrm{Li}^{+}$ consists of three framework $\mathrm{O}$ atoms and one $\mathrm{H}_{2} \mathrm{O}$ molecule. The $\mathrm{H}_{2} \mathrm{O}$ molecules are hydrogen-bonded to each other, forming onedimensional chains along the channel direction. At ambient conditions, the $\mathrm{H}_{2} \mathrm{O}$ molecules are also weakly hydrogen-bonded to the framework $\mathrm{O}$ atoms. The $\mathrm{H} P$-behaviour of $\mathrm{Li}-\mathrm{ABW}$ was investigated by Fois et al. (2008) by in situ synchrotron powder diffraction with a diamond anvil cell up to $9 \mathrm{GPa}$, using a non-penetrating $P$-transmitting medium. In the range $0-8.9 \mathrm{GPa}$, a nearly isotropic compression was observed, with an overall cell-volume decrease of $\sim 12 \%$. A change in the compressional behaviour (with a subtle discontinuity in the evolution of the unitcell parameters vs. $P$ ) was detected between 5 and $6 \mathrm{GPa}$. No high- $P$ structure refinements were carried out, but ab initio moleculardynamics simulations allowed description of the structure evolution in response to the applied pressure. The main deformation mechanisms, i.e. tilting of tetrahedra, lead to a strong compression of the channels. In response to channel deformation, the configuration of the $\mathrm{H}_{2} \mathrm{O}$ molecules changes, coupled with a rearrangement of the hydrogen-bonding pattern. The $P$-induced effects are completely reversible.

A study on ABW-type zeolites under extreme conditions was carried out by Gatta et al. (2008b, $2012 b)$ on $\mathrm{CsAlSiO}_{4}\left(P c 2_{1} n\right.$, lattice parameters: $a \approx 9.4, b \approx 5.4, c \approx 8.9 \AA$ ). The thermo-elastic behaviour of Cs-ABW was investigated up to $1000^{\circ} \mathrm{C}$ (at $0.0001 \mathrm{GPa}$ ) and up to $10 \mathrm{GPa}$ (at $20^{\circ} \mathrm{C}$ ) using in situ synchrotron powder-diffraction. No phase transition was observed within the temperature- and pressure-ranges investigated. The evolution of the lattice parameters with pressure shows a remarkably anisotropic compressional pattern, along with a subtle change in the axial elastic behaviour along [100] and [010] at $P>4 \mathrm{GPa}$. The structure of Cs-ABW has, in response to the applied $T$, a negative thermal expansion along [100], almost no expansion along [010] and a pronounced positive thermal expansion along [001]. The $P / T$-induced effects were found to be completely reversible within the $P / T$-range investigated.

\section{Comparative compressibility}

For a comparative elastic analysis of the aforementioned zeolites, we have modelled the compressional behaviour using the formalism of the isothermal Birch-Murnaghan Equation-ofState (BM-EoS, Birch, 1947; Angel, 2000). This EoS describes the compressional behaviour on the basis of the Helmholtz free energy on the assumption that the $P$-induced strain in a solid can be expressed as a Taylor series of the Eulerian strain:

$$
f_{\mathrm{E}}=\left[\left(V_{0} / V\right)^{2 / 3}-1\right] / 2
$$

( $V_{0}$ and $V$ are the cell volume, or molar volume, at room and $\mathrm{H} P$ conditions, respectively). Expansion of the Eulerian strain polynomial truncated to the fourth-order (in energy) has the following form:

$$
\begin{array}{r}
P=3 K_{0} f_{\mathrm{E}}\left(1+2 f_{\mathrm{E}}\right)^{5 / 2}\left\{1+1.5\left(K^{\prime}-4\right) f_{\mathrm{E}}+\right. \\
\left.1.5\left[K_{0} K^{\prime \prime}+\left(K^{\prime}-4\right)\left(K^{\prime}-3\right)+35 / 9\right] f_{\mathrm{E}^{2}}\right\}
\end{array}
$$

where $K_{0}$ is the bulk modulus $\left[K_{0}=\right.$ $-V_{0}(\partial P / \partial V)_{P=0}=1 / \beta_{0}$, where $\beta_{0}$ is the volume compressibility coefficient], $K^{\prime}=\left(\partial K_{0} / \partial P\right)$ and $K^{\prime \prime}$ $=\left(\partial^{2} K_{0} / \partial P^{2}\right)$. For modest $P$-regimes $($ and $/$ or for $V_{0} / V<10 \%$ ), a truncated second-order BM-EoS adequately describes the compressional behaviour of materials (i.e. with $K^{\prime}$ fixed at 4). Bulk moduli and their $P$-derivatives of zeolites so far studied at high- $P$ have been recalculated using the EOS-FIT program (Angel, 2000) and the data weighted by uncertainties in $P$ and $V$. The elastic parameters are summarized in Table 1.

The compressional behaviour is describable only if all the data used for the EoS-fit have been measured at a fixed composition: sets of data undergoing continuous change of chemical composition (e.g. due to over-hydration effects) were not considered. For experiments on both single crystals and powder, we used the more accurate single-crystal data for the EoS-fit.

\section{Pressure-induced structural evolution}

If we consider the $\mathrm{H} P$-structure models of zeolites, based on simulation or on structure refinements, we find three main $P$-induced responses to volume compression:

\section{(1)Tilting of tetrahedra}

One of the most common mechanisms observed in response to applied pressure is the tilting of the rigid tetrahedra around the $\mathrm{O}$ atoms that act as 
'hinges'. This mechanism does not lead to any distortion of the tetrahedra, but changes the $\mathrm{T}-\mathrm{O}-\mathrm{T}$ angles $v s . P$.

\section{(2) Tetrahedral distortion}

This mechanism implies distortion of the tetrahedra, with changes in the intra-tetrahedron $\mathrm{O}-\mathrm{T}-\mathrm{O}$ angles, but maintaining the average $\mathrm{T}-\mathrm{O}$ bond length.

\section{(3)Contraction of single $T-O$ bond lengths}

This mechanism implies polyhedron compression.

As already highlighted by Gatta $(2010 a, b)$, these three mechanisms act simultaneously in response to applied pressure, though with different magnitudes. Theoretical and experimental findings show that any framework reacts under compression first by tilting the tetrahedra, then distorting the tetrahedra and finally by contraction of the $\mathrm{T}-\mathrm{O}$ bond distances. This hierarchy reflects the fact that the tilting of tetrahedra is an energetically less-costly mechanism if compared to the other two mechanisms. In addition, the inter-tetrahedron tilting is independent of the nature of the $\mathrm{T}$ cations or on the bonding details of the bridging $\mathrm{O}$ atoms (i.e. O bonded to an extra-framework cation). In framework silicates, tetrahedron distortion and $\mathrm{T}-\mathrm{O}$ bond contraction become dominant mechanisms where the structure cannot accommodate tilting of tetrahedra any further under compression.

Evidence of the fact that zeolites tend to accommodate $P$-effects preferentially by tilting of tetrahedra (instead of distorting or compressing tetrahedra) is found in the $P$-induced structure evolution of levyne. Gatta et al. (2005) and Gatta and Wells (2006) observed that the framework of levyne responds under hydrostatic pressure by tilting of tetrahedra, with two distinct deformation mechanisms: the first predominant at low pressure $(P<1 \mathrm{GPa})$ and represented by cooperative rotation of tetrahedra belonging to the double six-membered rings (which leads to an increase of the $c$-axis between $0-1 \mathrm{GPa}$ ); the second at higher pressure $(P>1 \mathrm{GPa})$, by compression of the 'jointunit' between the six-membered rings (Fig. 3), where the double six-membered rings have already achieved a stable configuration. These two mechanisms are responsible for the anomalous elastic behaviour of levyne. Within the $P$ - range investigated (i.e. $0-5 \mathrm{GPa}$ ), there is no significant distortion or compression of the tetrahedra. In other words, levyne tends to accommodate the effect of pressure with a series of the deformation mechanisms based on tilting of tetrahedra. The majority of zeolites studied at high pressure do not show significant distortioncompression of the $\mathrm{Si} / \mathrm{Al}$-tetrahedra, at least up to 5-7 GPa. In such a $P$-range, $\mathrm{Si}$ - or Altetrahedra behave as 'rigid-units' at least to a first approximation. This is expected if we consider the stiffness of a $\mathrm{Si}$ or Al-tetrahedron (i.e. the estimated fictive bulk modulus of $\mathrm{SiO}_{4}$ is 580(24) GPa, Zhang et al., 1998). However, some zeolites, particularly those with high FD, respond to applied pressure with displacive phase transitions and the high-pressure polymorphs have distorted tetrahedra. This is the case of the zeolites belonging to Group 2 (i.e. zeolites with chains of corner-sharing four-membered rings) and in particular zeolites with ANA-framework type. As described by Gatta et al. (2006), analcime has a first-order phase transition at $\sim 1 \mathrm{GPa}$ from cubic to triclinic symmetry. Structure refinements of the low- and high- $P$ polymorphs showed that the main deformation mechanisms acting in the $\mathrm{H} P$-polymorph are governed by tilting of tetrahedra (by a strong distortion of the four- and sixmembered rings) coupled with distortion of the tetrahedra. These experimental findings are also predicted by the "flexibility window" theory: the tetrahedron deformation forced the structure to transform to lower symmetry, in order to accommodate the effects of the applied pressure (Sartbaeva et al., 2006, 2008; Gatta et al., 2009b; Wells et al., 2011).

A common feature is observed in the structure evolution of zeolites when compressed in a nonpenetrating medium: the ellipticity of the channels tends to increase monotonically with $P$, without any 'inversion' (Gatta and Lee, 2006). An 'inversion' in ellipticity at high- $P$ would probably lead to a phase transition, but this has not been observed so far. The opposite behaviour is observed where zeolites are compressed in penetrating $P$-fluids and where over-hydration creates new extra-framework sites and consequent channel expansion. In this case, the channels become more circular and the ellipticity decreases in response to over-hydration. An excellent example, in this respect, is that of natrolite (Lee et al., 2002a,b, 2010, 2011).

A further issue concerns the role of SBUs in the deformation mechanisms in zeolite at high 
pressure. Several studies (e.g. Gatta et al., 2003; Gatta, 2005) have shown that, in zeolite frameworks, it is possible to identify 'rigid SBUs', in particular where SBUs are represented by a discrete number of tetrahedra in 3D closed form. When compressed, some zeolitic structures respond first by rotating the SBUs (which behave as 'rigid block-units'), then by compressing the SBUs via tilting of tetrahedra and finally by deforming the tetrahedra themselves. An example of this is Group 1: zeolites with $\mathrm{T}_{5} \mathrm{O}_{10}$ units ('fibrous zeolites group'). Gatta (2005) reviewed the comparative $P$-induced behaviour of the fibrous-zeolite group. All fibrous zeolites show a similar deformation mechanism in response to applied pressure: cooperative anti-rotation of the SBU along the chain axis (Fig. 1). This mechanism compresses the channels of eight-membered rings with an increase in the pore ellipticity with $P$. The estimated fictive bulk modulus of the SBU is $110 \pm 15 \mathrm{GPa}$, which is significantly higher than the bulk moduli $\left[K_{0}(\right.$ FibZeol $)=50 \pm 10 \mathrm{GPa}$, Table 1]. The bulk modulus reflects the stiff SBU and the soft channels parallel to the SBU-chains (e.g. for scolecite: $K_{\mathrm{ch}}=17(2)$; for tetragonal edingtonite: $\left.K_{\text {ch }}=19(1) \mathrm{GPa}\right)$. Another zeolite group with 3D SBU is Group 6: zeolites of the heulandite group (or zeolites with $\mathrm{T}_{10} \mathrm{O}_{20}$ units). Comodi et al. (2001) showed that shortening of the zig-zag chains of SBU along [102] is the main deformation mechanism in heulandite in response to increasing hydrostatic pressure. Compression of the chains of SBU involves the T5-T5-T5 angle between the SBUs (Fig. 4), which decreases from $162.4(1)^{\circ}$ at $0.0001 \mathrm{GPa}$ to $156.2(3)^{\circ}$ at $3.40 \mathrm{GPa}$. The estimated fictive bulk modulus of the SBU is 63(8) GPa, whereas the bulk modulus of heulandite is $27.5(2) \mathrm{GPa}$ (Table 1). In response to the applied pressure, the channels are compressed, their ellipticity increases and their estimated bulk moduli are significantly low: 19(2) and 10(2) GPa for the ten- and eight-membered ring channels along [001], respectively, and 18(1) GPa for the eight-membered ring channels along [100]. The compressibility of the structure is thus the combined effect of soft channels and stiff 3D SBU.

An open question about the compressional behaviour of zeolites is the role played by the nature of the framework and extra-framework constituents, especially in isotypic materials. Once more, the fibrous-zeolite (FZ) group provides an excellent example of this. The frameworks of these zeolites consist of the same SBU but with different combinations of the SBUchains (Lee et al., 2000; Gatta, 2005). Natrolite (ideal chemical formula $\mathrm{Na}_{16} \mathrm{Al}_{16}$ $\left.\mathrm{Si}_{24} \mathrm{O}_{80} \cdot 16 \mathrm{H}_{2} \mathrm{O}\right)$, scolecite $\left(\mathrm{Ca}_{8} \mathrm{Al}_{16}\right.$ $\left.\mathrm{Si}_{24} \mathrm{O}_{80} \cdot 24 \mathrm{H}_{2} \mathrm{O}\right)$, thomsonite $\left(\mathrm{Na}_{4} \mathrm{Ca}_{8} \mathrm{Al}_{20}\right.$ $\mathrm{Si}_{20} \mathrm{O}_{80} \cdot 24 \mathrm{H}_{2} \mathrm{O}$ ) and edingtonite $\left(\mathrm{Ba}_{2} \mathrm{Al}_{4} \mathrm{Si}_{6} \mathrm{O}_{20} \cdot 8 \mathrm{H}_{2} \mathrm{O}\right)$ show the same main deformation mechanism of the framework in response to hydrostatic compression (Fig. 1): cooperative anti-rotation of the SBUs. Gatta (2005) analysed the role of the channel content on the compressibility and elastic anisotropy of the fibrous zeolites. The bulk modulus changes in response to the nature of the channel content, with $K_{0}(\mathrm{Ba}-\mathrm{FZ}$ in $\mathrm{EDI})>K_{0}(\mathrm{Ca}-\mathrm{FZ}$ in $\mathrm{NAT})>$ $K_{0}(\mathrm{Ca}+\mathrm{Na} \mathrm{FZ}$ in $\mathrm{THO})>K_{0}(\mathrm{Na}-\mathrm{FZ}$ in NAT $)$ (Table 1). However, the use of a simple relation between ionic radius of the extra-framework cations and the bulk moduli could not have a robust physical basis because the connectivity of the SBU's (as NAT, EDI, THO have different
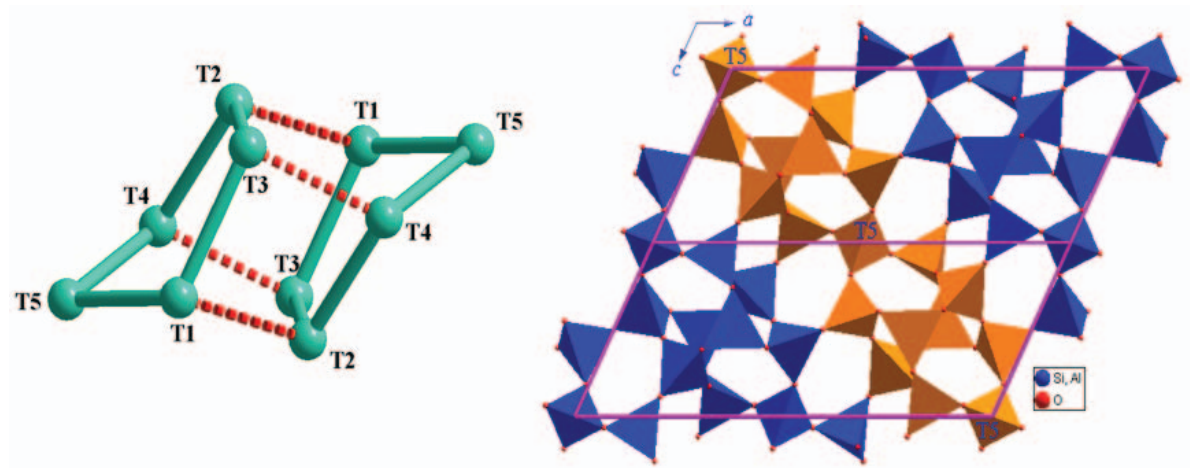

FIG. 4. The 4-4=1 SBU (or $\mathrm{T}_{10} \mathrm{O}_{20}$ unit) in the HEU framework-type and the SBU chains along [102]. In response to applied pressure, the T5-T5-T5 angle between the SBUs decreases. 
topology) and the bonding configuration of the channel content are completely different (i.e. two $\mathrm{Na}$-polyhedra with $\mathrm{CN}=7$ in $\mathrm{H} P$-natrolite; one Ca-polyhedra with $\mathrm{CN}=7$ in scolecite; one Bapolyhedra with $\mathrm{CN}=10$ in edingtonite). Gatta (2005) inferred that the different bulk moduli of the fibrous zeolites are due to a complex interaction of factors: (1) the different SBUs connectivity; (2) the bonding environment of the extra-framework cations; (3) the different roles of the H-bonding. It seems that the framework topology governs the main deformation mechanisms via tilting of tetrahedra, whereas the channel content controls the compressibility of the voids, which results in different compressibilities of unit-cell volumes in isotypic structures. Orthorhombic and tetragonal edingtonite show a fully ordered and a highly disordered Si/Aldistribution in the framework, respectively. The experiments of Gatta et al. $(2004 a, b)$ showed that ordering of the $\mathrm{Si} / \mathrm{Al}$ does not influence structure compressibility, which seems to be identical in orthorhombic and tetragonal edingtonite.

\section{Concluding remarks}

The comparative elastic analysis and the high- $P$ structural data of zeolites reported so far allow us to make some general conclusions:

(1) The range of compressibility among this class of open-framework silicates is significantly large, with $\sim 15<K_{0}<\sim 70$ GPa (Table 1). Comparative elastic analysis shows that microporosity does not necessarily imply high compressibility: several zeolites are less compressible than other non-zeolitic rock-forming minerals (e.g. $\alpha$-quartz, Angel et al., 1997; Na-rich feldspars, Benusa et al., 2005; Na-rich scapolites, Comodi et al., 1990; tri- and di-octahedral micas, Zanazzi and Pavese, 2002). Overall, we can infer that the compressibility of zeolites is not directly related to microporosity. If we represent the microporosity with the FD, the bulk moduli of the isotypic zeolites are different, even though their FD is similar (e.g. natrolite and scolecite, Table 1). On the other hand, zeolites belonging to different groups show drastically different bulk moduli despite their similar FD (e.g. scolecite and heulandite, Table 1). Thus it does not seem possible to express the elastic parameters of zeolites as a function of framework density.

Zeolites are generally expected to behave as soft materials because of their porous nature. However, this is true only for zeolites with empty cavities (e.g. see the different elastic behaviour of mutinaite and silicalite, Quartieri et al., 2011). For zeolites with extra-framework species, bonding between the host framework and guest species (cations and $\mathrm{H}_{2} \mathrm{O}$ molecules) significantly affects the overall compression behaviour.

(2) The flexibility observed in zeolites under hydrostatic compression is based mainly on tilting of rigid tetrahedra around $\mathrm{O}$ atoms that behave as hinges. $P$-induced tilting of tetrahedra usually leads to the continuous rearrangement of the framework without any phase transition. More rarely, tilting induces displacive phase transitions (e.g. for analcime-type materials). Baur (1992), Baur et al. (1996) and Ross (2000) suggested a model to explain the flexibility based on the "noncollapsibility' of frameworks, through self-regulating mechanisms involving anti-rotation of tetrahedra about hinges in response to different $P-T-X$ conditions. The anti-rotation mechanisms simultaneously induce 'compression' and 'extension' inside the framework, as compression around one hinge necessitates expansion around another hinge. Overall, we can infer that openframework silicates have structural flexibility to sustain the applied pressure, even toward structural configurations that are energetically costly (i.e. with $\mathrm{T}-\mathrm{O}-\mathrm{T}$ angle $\leqslant 120^{\circ}$ ) and maintain their topological symmetry up to the onset of amorphization. $P$-induced reconstructive phase transitions, without the concomitant effect of $T$, probably do not occur in this class of materials.

(3) As observed for isotypic zeolites (e.g. fibrous zeolites, cancrinite-type materials), the deformation mechanisms in response to the applied pressure are dictated by the topological configuration of the tetrahedral framework and are independent of the Si/Al-distribution and of the channel species. The channel content (with its different nature and bonding configuration) governs the compressibility of the cavities, leading to different unit-cell-volume compressibility in isotypic structures.

(4) In some zeolitic frameworks, it is possible to identify 'rigid units' represented by a discrete number of tetrahedra in $3 \mathrm{D}$ closed form. This is the case for zeolites belonging to Group 1 (zeolites with $\mathrm{T}_{5} \mathrm{O}_{10}$ units) and Group 6 (zeolites with $\mathrm{T}_{10} \mathrm{O}_{20}$ units), with frameworks based on SBU's with 3D closed forms. The SBUs are not completely rigid and contribute to the general compressibility of the structure by tilting of tetrahedra. 
(5) In zeolites, the effects of pressure are accommodated usually by increasing the ellipticity of the channel systems, though without inversion in ellipticity (Gatta and Lee, 2006).

(6) The effect of pressure on the structural evolution of zeolites seems to be more dramatic than that of temperature, where no $P$-induced over-hydration or $T$-induced dehydration effects occur. Analcime is an excellent example of this. At high $T$, tetragonal analcime shows a complete loss of $\mathrm{H}_{2} \mathrm{O}$ at $923^{\circ} \mathrm{C}$ (Cruciani and Gualtieri, 1999). The tetragonal structure is preserved and no phase transition is observed at least up to $\sim 1270^{\circ} \mathrm{C}$, where evidence of an evolution toward a cubic structure is reported. The high- $T$ leads to a significant change of the bonding environment of the extra-framework content, in response to the dehydration process. However, the general configuration of the tetrahedral framework is maintained. In contrast, analcime-type zeolites have a first-order phase transition under moderate pressure, from high symmetry to low symmetry with a dramatic distortion of the framework (Gatta et al., 2006).

The description of the main deformation mechanisms and the comparative elastic analysis, resulting in the general considerations reported above, reflect what we have so far learned about the $\mathrm{H} P$-behaviour of zeolites along with some open questions. In general, we can predict the elastic anisotropy of a given zeolite on the basis of the channel configuration, following the postulate of Gatta and Lee (2006). However, we cannot predict its volume compressibility on the basis of its microporosity. A further issue is the prediction of the $P$-induced phase stability of zeolites. In this respect, the "flexibility window" theory seems promising, in particular if we consider the results of its application to analcime-type zeolites (Sartbaeva et al., 2006, 2008; Gatta et al., 2009b; Wells et al., 2011).

\section{Acknowledgements}

G.D. Gatta thanks the Italian Ministry of Education, MIUR-Project: 'Futuro in Ricerca 2012-ImPACT- RBFR12CLQD'. Y. Lee is grateful for the support of the Global Research Laboratory program of the Korean Ministry of Science, ICT and Future Planning (MSIP). F. Hawthorne and two anonymous reviewers are thanked.

\section{References}

Ackley, M.W., Rege, S.U. and Saxena, H. (2003) Application of natural zeolites in the purification and separation of gases. Microporous and Mesoporous Materials, 61, 25-42.

Angel, R.J. (2000) Equation of state. Pp. 35-59 in: High-Temperature and High-Pressure Crystal Chemistry (R.M. Hazen, R.T. Downs, editors). Reviews in Mineralogy \& Geochemistry, 41. Mineralogical Society of America and the Geochemical Society, Washington, DC.

Angel, R.J., Allan, D.R., Miletich, R. and Finger, L.W. (1997) The use of quartz as an internal pressure standard in high-pressure crystallography. Journal of Applied Crystallography, 30, 461-466.

Angel, R.J., Bujak, M., Zhao, J., Gatta, G.D. and Jacobsen, S.J. (2007) Effective hydrostatic limits of pressure media for high-pressure crystallographic studies. Journal of Applied Crystallography, 40, $26-32$.

Armbruster, T. and Gunter, M.E. (2001) Crystal structures of natural zeolites. Pp. 1-57 in: Natural Zeolites: Occurrence, Properties, Application (D.L. Bish and D.W. Ming, editors). Reviews in Mineralogy \& Geochemistry, 45. Mineralogical Society of America and the Geochemical Society, Washington, DC.

Arletti, R., Ferro O., Quartieri, S., Sani, A., Tabacchi, G. and Vezzalini, G. (2003) Structural deformation mechanisms of zeolites under pressure. American Mineralogist, 88, 1416-1422.

Arletti, R., Quartieri, S. and Vezzalini, G. (2010) Elastic behavior of zeolite boggsite in silicon oil and aqueous medium: A case of high-pressure-induced over-hydration. American Mineralogist, 95, 1247-1256.

Arletti, R., Vezzalini, G., Morsli, A., Di Renzo, F., Dmitriev, V. and Quartieri, S. (2011) Elastic behavior of MFI-type zeolites: 1 - Compressibility of Na-ZSM-5 in penetrating and non-penetrating media. Microporous and Mesoporous Materials, 142, 696-707.

Baerlocher, C., McCusker, L.B. and Olson, D.H. (2007) Atlas of Zeolite Framework Types (sixth edition), Elsevier, Amsterdam, 84 pp.

Ballone, P., Quartieri, S., Sani, A. and Vezzalini, G. (2002) High-pressure deformation mechanism in scolecite: A combined computational-experimental study. American Mineralogist, 87, 1194-1206.

Baur, W.H. (1992) Self-limiting distortion by antirotating hinges is the principle of flexible but noncollapsable framework. Journal of Solid State Chemistry, 97, 243-247.

Baur, W.H., Joswig, W. and Müller, G. (1996) Mechanisms of the feldspar framework: crystal structure of Li-feldspar. Journal of Solid State 
Chemistry, 12, 12-23.

Baur, W.H. and Fischer, R.X. (editors) (2000) ZeoliteType Crystal Structures and their Chemistry. Zeolite Structure Codes $A B W$ to $C Z P$. Landolt-Börnstein, Subvolume B, Numerical Data and Functional Relationships in Science and Technology, New Series, Group IV: Physical Chemistry. Microporous and other Framework Materials with Zeolite-Type Structures, 14B. Springer-Verlag, Berlin. p. 459.

Benusa, M.T., Angel, R.J. and Ross, N.L. (2005) Compression of albite, $\mathrm{NaAlSi}_{3} \mathrm{O}_{8}$. American Mineralogist, 90, 1115-1120.

Besson, J.M., Nelmes, R.J., Hamel, G., Loveday, J.S., Weill, G. and Hull, S. (1992) Neutron powder diffraction above $10 \mathrm{GPa}$. Physica B: Physics of Condensed Matter, 180, 907-910.

Betti, C., Fois, E., Mazzuccato, E., Medici, C., Quartieri, S., Tabacchi, G., Vezzalini, G. and Dmitriev, V. (2007) Gismondine under HP: Deformation mechanism and re-organization of the extra-framework species. Microporous and Mesoporous Materials, 103, 190-209.

Birch, F. (1947) Finite elastic strain of cubic crystals. Physical Review, 71, 809-824.

Bish, D.L. and Carey, J.W. (2001) Thermal behavior of natural zeolites. Pp. 403-452 in: Natural Zeolites: Occurrence, Properties, Application (D.L. Bish and D.W. Ming, editors). Reviews in Mineralogy \& Geochemistry, 45. Mineralogical Society of America and the Geochemical Society, Washington, DC.

Bish, D.L., Vaniman, D.T., Chipera, S.J. and Carey, J.W. (2003) The distribution of zeolites and their effects on the performance of a nuclear waste repository at Yucca Mountain, Nevada, USA. American Mineralogist, 88, 1889-1902.

Colella, C. (2011) A critical reconsideration of biomedical and veterinary applications of natural zeolites. Clay Minerals, 46, 295-309.

Colligan, M., Forster, P.M., Cheetham, A.K., Lee, Y., Vogt, T. and Hriljac, J.A. (2004) Synchrotron X-ray powder diffraction and computational investigation of purely siliceous zeolite Y under pressure. Journal of American Chemical Society, 126, 12015-12022.

Colligan, M., Lee, Y., Vogt, T., Celestian, A ., Parise, J.B., Marshall, W. and Hriljac, J. (2005) Highpressure Neutron powder diffraction study of superhydrated natrolite. Journal of Physical Chemistry B, 109, 18223-18225.

Comodi, P., Mellini, M. and Zanazzi, P.F. (1990) Scapolites: Variation of structure with pressure and possible role in the storage of fluids. European Journal of Mineralogy, 2, 195-202.

Comodi, P., Gatta, G.D. and Zanazzi, P.F. (2001) Highpressure structural behavior of heulandite. European Journal of Mineralogy, 13, 497-505.

Comodi, P., Gatta, G.D. and Zanazzi, P.F. (2002) High- pressure behaviour of scolecite. European Journal of Mineralogy, 14, 567-574.

Comodi, P., Gatta, G.D. and Zanazzi, P.F. (2003) Effects of pressure on the structure of bikitaite. European Journal of Mineralogy, 15, 247-225.

Coombs, D.S., Alberti, A., Armbruster, T., Artioli, G., Colella, C., Galli, E., Grice, J.D., Liebau, F., Mandarino, J.A., Minato, H., Nickel, E.H., Passaglia, E., Peacor, D.R., Quartieri, S., Rinaldi, R., Ross, M., Sheppard, R. A., Tillmanns, E. and Vezzalini, G. (1997) Recommended nomenclature for zeolite minerals: report of the Subcommittee on Zeolites of the International Mineralogical Association, Commission on new minerals and minerals names. The Canadian Mineralogist, 35, $1571-1606$.

Cruciani, G. (2006) Zeolites upon heating: Factors governing their thermal stability and structural changes. Journal of Physics and Chemistry of Solids, 67, 1973-1994.

Cruciani, G. and Gualtieri, A. (1999) Dehydration dynamics of analcime by in situ synchrotron powder diffraction. American Mineralogist, 84, 112-119.

Ferro, O., Quartieri, S., Vezzalini, G., Fois, E., Gamba, A. and Tabacchi, G. (2002) High-pressure behaviour of bikitaite: An integrated theoretical and experimental approach. American Mineralogist, 87, $1415-1425$.

Fois, E., Tabacchi, G., Quartieri, S. and Vezzalini, G. (1999) Dipolar host/guest interactions and geometrical confinement at the basis of the stability of onedimensional ice in zeolite bikitaite. Journal of Chemical Physics, 111, 355-359.

Fois, E., Gamba, A., Tabacchi, G., Arletti, R., Quartieri, S. and Vezzalini, G. (2005) The "template" effect of the extra-framework content on zeolite compression: The case of yugawaralite. American Mineralogist, 90, 28-35.

Fois, E., Gamba, A., Medici, C., Tabacchi, G., Quartieri, S., Mazzucato, E., Arletti, R., Vezzalini, G. and Dmitriev, V. (2008) High pressure deformation mechanism of Li-ABW: Synchrotron XRPD study and $\mathrm{ab}$ initio molecular dynamics simulations. Microporous and Mesoporous Materials, 115, 267-280.

Fütterer, K., Depmeier, W., Altdorfer, F., Behrens, P. and Felsche, J. (1994) Compression mechanism in trioxane silica sodalite $\left[\mathrm{Si}_{12} \mathrm{O}_{24}\right] \cdot 2 \mathrm{C}_{3} \mathrm{H}_{6} \mathrm{O}_{3}$. Zeitschrift für Kristallographie, 209, 517-523.

Galli, E., Vezzalini, G., Quartieri, S., Alberti, A. and Franzini, M. (1997) Mutinaite, a new zeolite from Antartica: The natural counterpart of ZSM-5. Zeolites, 19, 318-322.

Gatta, G.D. (2005) A comparative study of fibrous zeolites under pressure. European Journal of Mineralogy, 17, 411-422. 
Gatta, G.D. (2008) Does porous mean soft? On the elastic behaviour and structural evolution of zeolites under pressure. Zeitschrift für Kristallographie, 223, $160-170$.

Gatta, G.D. (2010a) Extreme deformation mechanisms in open-framework silicates at high-pressure: Evidence of anomalous inter-tetrahedral angles. Microporous and Mesoporous Materials, 128, $78-84$.

Gatta, G.D. (2010b) Microporous materials at high pressure: Are they really soft? Pp. 481-491 in: High-Pressure Crystallography: From Fundamental Phenomena to Technological Applications (E. Boldyreva and P. Dera, editors). NATO Science for Peace and Security - Series B (Physics and Biophysics), Springer Science. http://dx.doi.org/ 10.1007/978-90-481-9258-8 39.

Gatta, G.D. and Lee, Y. (2006) On the elastic behaviour of zeolite mordenite: a synchrotron powder diffraction study. Physics and Chemistry of Minerals, 32, $726-732$.

Gatta, G.D. and Lee, Y. (2007) Anisotropic elastic behaviour and structural evolution of zeolite phillipsite at high pressure: A synchrotron powder diffraction study. Microporous and Mesoporous Materials, 105, 239-250.

Gatta, G.D. and Lee, Y. (2008) Pressure-induced structural evolution and elastic behaviour of $\mathrm{Na}_{6} \mathrm{Cs}_{2} \mathrm{Ga}_{6} \mathrm{Ge}_{6} \mathrm{O}_{24} \cdot \mathrm{Ge}(\mathrm{OH})_{6}$ variant of cancrinite: a synchrotron powder diffraction study. Microporous and Mesoporous Materials, 116, 51-58.

Gatta, G.D. and Wells, S.A. (2004) Rigid unit modes at high pressure: an explorative study of a fibrous zeolite-like framework with EDI topology. Physics and Chemistry of Minerals, 31, 465-474.

Gatta, G.D. and Wells, S.A. (2006) Structural evolution of zeolite levyne under hydrostatic and nonhydrostatic pressure: geometric modelling. Physics and Chemistry of Minerals, 33, 243-255.

Gatta, G.D., Comodi, P. and Zanazzi, P.F. (2003) New insights on high-pressure behaviour of microporous materials from X-ray single-crystal data. Microporous and Mesoporous Materials, 61, 105-115.

Gatta, G.D., Boffa Ballaran, T., Comodi, P. and Zanazzi, P.F. (2004a) Isothermal equation of state and compressional behaviour of tetragonal edingtonite. American Mineralogist, 89, 633-639.

Gatta, G.D., Boffa Ballaran, T., Comodi, P. and Zanazzi, P.F. (2004b) Comparative compressibility and equation of state of orthorhombic and tetragonal edingtonite. Physics and Chemistry of Minerals, 31, $288-298$

Gatta, G.D., Comodi, P., Zanazzi, P.F. and Boffa Ballaran, T. (2005) Anomalous elastic behavior and high-pressure structural evolution of zeolite levyne.
American Mineralogist, 90, 645-652.

Gatta, G.D., Nestola, F. and Boffa Ballaran, T. (2006) Elastic behavior, phase transition and pressure induced structural evolution of analcime. American Mineralogist, 91, 568-578.

Gatta, G.D., Rotiroti, N., Boffa Ballaran, T. and Pavese, A. (2008a) Leucite at high-pressure: elastic behaviour, phase stability and petrological implications. American Mineralogist, 93, 1588-1596.

Gatta, G.D., Rotiroti, N., Zanazzi, P.F., Rieder, M., Drabek, M., Weiss, Z. and Klaska R. (2008b) Synthesis and crystal structure of the feldspathoid $\mathrm{CsAlSiO}_{4}$ : an open-framework silicate and potential nuclear waste disposal phase. American Mineralogist, 93, 988-995.

Gatta, G.D., Rotiroti, N., Boffa Ballaran, T., SanchezValle, C. and Pavese, A. (2009a) Elastic behavior and phase-stability of pollucite, a potential host for nuclear waste. American Mineralogist, 94, 1137-1143.

Gatta, G.D., Sartbaeva, A. and Wells, A.S. (2009b) Compression behaviour and flexibility window of the analcime-like feldspathoids: experimental and theoretical findings. European Journal of Mineralogy, 21, 571-580.

Gatta, G.D., Lotti, P., Nestola, F. and Pasqual, D. (2012a) On the high-pressure behavior of gobbinsite, the natural counterpart of the synthetic zeolite Na-P2. Microporous and Mesoporous Materials, 163, 259-269.

Gatta, G.D., Merlini, M., Lotti, P., Lausi, A. and Rieder, M. (2012b) Phase stability and thermo-elastic behavior of $\mathrm{CsAlSiO}_{4}$ (ABW): A potential nuclear waste disposal material. Microporous and Mesoporous Materials, 163, 147-152.

Gillet, P., Malézieux, J.M. and Itié, J.P. (1996) Phase changes and amorphization of zeolites at high pressure: The case of scolecite and mesolite. American Mineralogist, 81, 651-657.

Goryainov, S.V. (2005) Pressure-induced amorphization of $\mathrm{Na}_{2} \mathrm{Al}_{2} \mathrm{Si}_{3} \mathrm{O}_{10} \cdot 2 \mathrm{H}_{2} \mathrm{O}$ and $\mathrm{KAlSi}_{2} \mathrm{O}_{6}$ zeolites. Physica Status Solidi, 202, R25-R27.

Gottardi, G. and Galli, E. (1985) Natural Zeolites. Springer-Verlag, Berlin, 409 pp.

Greaves, G.N., Meneau, F., Sapelkin, A., Colyer, L.M., Gwynn, I.A., Wade, S. and Sankar, G. (2003) The rheology of collapsing zeolites amorphized by temperature and pressure. Nature Materials, 2, $622-629$.

Gulín-González, J. and Suffritti, G.B. (2004) Amorphization of calcined LTA zeolites at high pressure: a computational study. Microporous and Mesoporous Materials, 69, 127-134.

Haines, J., Levelut, C., Isambert, A., Hebert, P., Kohara, S., Keen, D.A., Hammouda, T. and Andrault, D. (2009) Topologically ordered amorphous silica 
obtained from the collapsed siliceous zeolite, silicalite-1-F: A step toward "perfect" glasses. Journal of the American Chemical Society, 131, 12333-12338.

Haines, J., Cambon, O., Levelut, C., Santoro, M., Gorelli, F. and Garbarino, G. (2010) Deactivation of pressure-induced amorphization in silicalite $\mathrm{SiO}_{2}$ by insertion of guest species. Journal of American Chemical Society, 132, 8860-8861.

Hay, R.L. and Sheppard, R.A. (2001) Occurrence of zeolites in sedimentary rocks: An overview. Pp. 217-234 in: Natural Zeolites: Occurrence, Properties, Application (D.L. Bish and D.W. Ming, editors). Reviews in Mineralogy \& Geochemistry, 45. Mineralogical Society of America and the Geochemical Society, Washington, DC.

Hazen, R.M. (1983) Zeolite molecular sieve 4A: anomalous compressibility and volume discontinuities at high pressure. Science, 219, 1065-1067.

Hazen, R.M. and Finger, L.W. (1979) Polyhedral tilting: a common type of pure displacive phase transition and its relationship to analcite at high pressure. Phase Transitions, 1, 1-22.

Hazen, R.M. and Finger, L.W. (1984) Compressibility of zeolite $4 \mathrm{~A}$ is dependent on the molecular size of the hydrostatic pressure medium. Journal of Applied Physics, 56, 1838-1840.

Hazen, R.M. and Sharp, Z.D. (1988) Compressibility of sodalite and scapolite. American Mineralogist, 73, $1120-1122$.

Huang, Y. and Havenga, E.A (2001) Why do zeolites with LTA structure undergo reversible amorphization under pressure? Chemical Physics Letter, 345, $65-71$.

Isambert, A., Angot, E., Hébert, P., Haines, J., Levelut, C., Le Parc, R., Ohishi, Y., Koharad, S. and Keenef, D.A. (2008) Amorphization of faujasite at high pressure: an X-ray diffraction and Raman spectroscopy study. Journal of Material Chemistry, 18, 5746-5752.

Jang, Y.N., Kao, C.C., Vogt, T. and Lee, Y. (2010) Anisotropic compression of a synthetic potassium aluminogermanate zeolite with gismondine topology. Journal of Solid State Chemistry, 183, 2305-2308.

Kahlenberg, V., Fischer, R.X. and Baur, W.H. (2001) Symmetry and structural relationships among ABWtype materials. Zeitschrift für Kristallographie, 216, 489-494.

Kalló, D. (2001) Applications of natural zeolites in water and wastewater treatment. Pp. 519-550 in: Natural Zeolites: Occurrence, Properties, Application (D.L. Bish and D.W. Ming, editors). Reviews in Mineralogy \& Geochemistry, 45. Mineralogical Society of America and the Geochemical Society, Washington, DC.
Klotz, S., Chervin, J.-C., Munsch, P. and Le Marchand, G. (2009) Hydrostatic limits of 11 pressure transmitting media. Journal of Physics D: Applied Physics, 42, 075413.

Komarneni, S. (1985) Philipsite in Cs decontamination and immobilization. Clays and Clay Minerals, 33, $145-151$.

Knorr, K., Braunbarth, C.M., van de Goor, G., Behrens, P., Griewatsch, C. and Depmeier W. (2000) Highpressure study on dioxolane silica sodalite $\left(\mathrm{C}_{3} \mathrm{H}_{6} \mathrm{O}_{2}\right)_{2}\left[\mathrm{Si}_{12} \mathrm{O}_{24}\right]$ - neutron and X-ray powder diffraction experiments. Solid State Communications, 113, 503-507.

Langella, A., Cappelletti, P. and de' Gennaro, R. (2001) Zeolites in closed hydrologic systems. Pp. 235-260 in: Natural Zeolites: Occurrence, Properties, Application (D.L. Bish and D.W. Ming, editors). Reviews in Mineralogy \& Geochemistry, 45. Mineralogical Society of America and the Geochemical Society, Washington, DC.

Leardini, L., Quartieri, S. and Vezzalini, G. (2010) Compressibility of microporous materials with CHA topology: 1. Natural chabazite and SAPO-34. Microporous and Mesoporous Materials, 127, 219-227.

Leardini, L., Quartieri, S., Martucci, A., Vezzalini, G. and Dmitriev, V. (2012) Compressibility of microporous materials with CHA topology: 2. ALPO-34. Zeitschrift für Kristallographie, 227, 514-521.

Leardini, L., Quartieri, S. and Vezzalini, G., Martucci, A. and Dmitriev, V. (2013) Elastic behavior and high pressure-induced phase transition in chabazite: New data from a natural sample from Nova Scotia. Microporous and Mesoporous Materials, 170, 52-61.

Lee, Y., Kim, S.J. and Parise, J.B. (2000) Synthesis and crystal structures of gallium- and germaniumvariants of the fibrous zeolites with the NAT, EDI and THO structure types. Microporous and Mesoporous Materials, 34, 255-271.

Lee, Y., Hriljac, J.A., Vogt, T., Parise, J.B., Edmondson, M., Anderson, P., Corbin, D. and Nagai, T. (2001) Phase transition of zeolite Rho at high-pressure. Journal of the American Chemical Society, 123, 8418-8419.

Lee, Y., Vogt, T., Hriljac, J.A., Parise, J.B. and Artioli, G. (2002a) Pressure-induced volume expansion of zeolites in the natrolite family. Journal of the American Chemical Society, 124, 5466-5475.

Lee, Y., Vogt, T., Hriljac, J.A., Parise, J.B., Hanson, J.C. and Kimk, S.J. (2002b) Non-framework cation migration and irreversible pressure-induced hydration in a zeolite. Nature, 420, 485-489.

Lee, Y., Hriljac, J.A., Studer, A. and Vogt, T. (2004a) Anisotropic compression of edingtonite and thomsonite to $6 \mathrm{GPa}$ at room temperature. Physics and 
Chemistry of Minerals, 31, 22-27.

Lee, Y., Hriljac, J.A. and Vogt, T. (2004b) Pressureinduced migration of zeolitic water in laumontite. Physics and Chemistry of Minerals, 31, 421-428.

Lee, Y., Martin, D., Hriljac, J.A. and Vogt, T. (2004c) Formation and manipulation of confined water wires. Nanoletters, 4, 619-621.

Lee, Y., Hriljac, J.A., Parise, J.B. and Vogt, T. (2005) Pressure-induced stabilization of ordered paranatrolite: a solution to the paranatrolite controversy. American Mineralogist, 90, 252-257.

Lee, Y., Kim, S.J., Kao, C.C. and Vogt, T. (2008) Pressure-induced hydration and order-disorder transition in a synthetic potassium gallosilicate zeolite with gismondine topology. Journal of the American Chemical Society, 130, 2842-2850.

Lee,Y., Hriljac, J.A. and Vogt, T. (2010) Pressureinduced argon insertion into an auxetic small pore zeolite. Journal of Physical Chemistry C, 114, 6922-6927.

Lee, Y., Liu, D., Seoung, D., Liu, Z., Kao, C.C. and Vogt, T. (2011) Pressure- and heat-induced insertion of $\mathrm{CO}_{2}$ into an auxetic small-pore zeolite. Journal of American Chemical Society, 133, 1674-1677.

Lee, Y., Seoung, D., Im, J.H., Hwang, H.J., Kim, T.H., Liu, D., Liu, Z., Lee, S.Y., Kao, C.C. and Vogt, T. (2012) Immobilization of large, aliovalent cations in the small-pore zeolite K-natrolite by means of pressure. Angewandte Chemie International Edition, 51, 4848-4851.

Likhacheva, A.Y., Seryotkin, Y.V., Manakov, A.Y., Goryainov, S.V., Ancharov, A.I. and Sheromov, M.A. (2006) Anomalous compression of scolecite and thomsonite in aqueous medium to $2 \mathrm{GPa}$. High Pressure Research, 26, 449-453.

Likhacheva, A.Y., Seryotkin, Y.V., Manakov, A.Y., Goryainov, S.V., Ancharov, A.I. and Sheromov, M.A. (2007) Pressure-induced over-hydration of thomsonite: a synchrotron powder diffraction study. American Mineralogist, 92, 1610-1615.

Likhacheva, A.Y., Malyshev, M.E., Manakov, A.Y., Goryainov, S.V. and Ancharov, A.I. (2009) Nonhydrostatic compression of zeolite $\mathrm{NaA}$ in water medium: connection to anomalous conductivity. Zeitschrift für Kristallographie, 224, 137-143.

Lotti, P., Gatta, G.D., Rotiroti, N. and Cámara, F. (2012) High-pressure study of a natural cancrinite. American Mineralogist, 97, 872-882.

Lotti, P., Gatta, G.D., Rotiroti, N., Cámara, F. and Harlow, G.E. (2014) The high-pressure behavior of balliranoite: a cancrinite-group mineral. Zeitschrift für Kristallographie - Crystalline Materials 229, 6376. http://dx.doi.org/10.1515/zkri-2014-1626.

Mao, H.K., Xu, J. and Bell, P.M. (1986) Calibration of the ruby pressure gauge to $800 \mathrm{kbar}$ under quasihydrostatic conditions. Journal of Geophysical
Research, 91, 4673-4676.

Maxwell, I.E. and Stork, W.H.J. (2001) Hydrocarbon processing with zeolites. Studies in Surface Science and Catalysis, 137, 747-819.

Mazzi, F. and Galli, E. (1978) Is each analcime different? American Mineralogist, 63, 448-460.

Merrill, L. and Bassett, W.A. (1974) Miniature diamond anvil pressure cell for single-crystal X-ray diffraction studies. Review of Scientific Instruments, 45, 290-294.

Miletich, R., Allan, D.R. and Kuhs, W.F. (2000) Highpressure single-crystal techniques. Pp. 445-519 in: High-Temperature and High-Pressure Crystal Chemistry (R.M. Hazen, R.T. Downs, editors). Reviews in Mineralogy \& Geochemistry, 41. Mineralogical Society of America and the Geochemical Society, Washington, DC.

Ming, D.W. and Allen, E.R. (2001) Use of natural zeolites in agronomy, horticulture, and environmental soil remediation. Pp. 619-654 in: Natural Zeolites: Occurrence, Properties, Application (D.L. Bish and D.W. Ming, editors). Reviews in Mineralogy \& Geochemistry, 45. Mineralogical Society of America and the Geochemical Society, Washington, DC.

Mumpton, F.A. (1999) La roca magica: Uses of natural zeolites in agriculture and industry. Proceedings of the National Academy of Sciences USA, 96, 3463-3470.

Ori, S., Quartieri, S., Vezzalini, G. and Dmitriev, V. (2008a) Pressure-induced over-hydration and water ordering in gismondine: A synchrotron powder diffraction study. American Mineralogist, 93, 1393-1403.

Ori, S., Quartieri, S., Vezzalini, G. and Dmitriev, V. (2008b) Pressure-induced structural deformation and elastic behavior of wairakite. American Mineralogist, 93, 53-62.

Pabalan, R.T. and Bertetti, F.P. (2001) Cation-exchange properties of natural zeolites. Pp. 453-518 in: Natural Zeolites: Occurrence, Properties, Application (D.L. Bish and D.W. Ming, editors). Reviews in Mineralogy \& Geochemistry, 45. Mineralogical Society of America and the Geochemical Society, Washington, DC.

Quartieri, S., Montagna, G., Arletti, R. and Vezzalini, G. (2011) Elastic behavior of MFI-type zeolites: Compressibility of H-ZSM-5 in pentrating and nonpenetrating media. Journal of Solid State Chemistry, 184, 1505-1516.

Quartieri, S., Arletti, R., Vezzalini, G., Di Renzo, F., and Dmitriev, V. (2012) Elastic behavior of MFI-type zeolites: 3 - Compressibility of silicalite and mutinaite. Journal of Solid State Chemistry, 191, $201-212$.

Ross, N.L. (2000) Framework structures. Pp. 257-287 
in: High-Temperature and High-Pressure Crystal Chemistry (R.M. Hazen, R.T. Downs, editors). Reviews in Mineralogy \& Geochemistry, 41. Mineralogical Society of America and the Geochemical Society, Washington, DC.

Rutter, M.D., Secco, R.A. and Huang, Y. (2000) Ionic conduction in hydrated zeolite Li-, Na- and K-A at high pressures. Chemical Physics Letter, 331, 189-195.

Rutter, M.D., Uchida T., Secco, R.A., Huang, Y. and Wang, Y. (2001) Investigation of pressure-induced amorphization in hydrated zeolite $\mathrm{Li}-\mathrm{A}$ and $\mathrm{Na}-\mathrm{A}$ using synchrotron X-ray diffraction. Journal of Physics and Chemistry of Solids, 62, 599-606.

Sanchez-Valle, C., Sinogeikin, S.V., Lethbridge, Z.A.D., Evans, K.E. and Bass, J.D. (2005) Brillouin scattering study on the single-crystal elastic properties of natrolite and analcime zeolites. Journal of Applied Physics, 98, 053508 (1-6).

Sanchez-Valle, C., Chi-Hong, C. and Gatta, G.D. (2010) Single-crystal elastic properties of $(\mathrm{Cs}, \mathrm{Na}) \mathrm{AlSi}_{2} \mathrm{O}_{6} \cdot \mathrm{H}_{2} \mathrm{O}$ pollucite: with potential use for long-term storage of Cs radioisotopes. Journal of Applied Physics, 108, 093509 (1-7).

Sartbaeva, A., Wells, S.A., Treacy, M.M.J. and Thorpe, M.F. (2006) The flexibility window in zeolites. Nature Materials, 5, 962-965.

Sartbaeva, A., Gatta, G.D. and Wells, S.A. (2008) Flexibility window controls pressure-induced phase transition in analcime. Europhysics Letters, 83, 26002.

Secco, R.A. and Huang, Y. (1999) Pressure-induced disorder in hydrated Na-A zeolite. Journal of Physics and Chemistry of Solids, 60, 999-1002.

Seryotkin, Y.V., Bakakin, V.V., Fursenko, B.A., Belitsky, I.A., Joswig, W. and Radaelli, P.G. (2005) Structural evolution of natrolite during overhydration: a high-pressure neutron diffraction study. European Journal of Mineralogy, 17, 305-313.

Sheppard, R.A. and Hay, R.L. (2001) Formation of zeolites in open hydrologic systems. Pp. 261-276 in: Natural Zeolites: Occurrence, Properties, Application (D.L. Bish and D.W. Ming, editors). Reviews in Mineralogy \& Geochemistry, 45. Mineralogical Society of America and the Geochemical Society, Washington, DC.

U.S. Geological Survey (2013) Mineral Commodity Summaries 2013. US Geological Survey, Reston,
Virginia, USA. 198 pp. (ISBN 978-1-41133548-6).

Utada, M. (2001a) Zeolites in burial diagenesis and lowgrade metamorphic rocks. Pp. 277-304 in: Natural Zeolites: Occurrence, Properties, Application (D.L. Bish and D.W. Ming, editors). Reviews in Mineralogy \& Geochemistry, 45. Mineralogical Society of America and the Geochemical Society, Washington, DC.

Utada, M. (2001b) Zeolites in hydrothermally altered rocks. Pp. 305-322 in: Natural Zeolites: Occurrence, Properties, Application (D.L. Bish and D.W. Ming, editors). Reviews in Mineralogy \& Geochemistry, 45. Mineralogical Society of America and the Geochemical Society, Washington, DC.

Vezzalini, G., Quartieri, S., Galli, E., Alberti, A., Cruciani, G. and Kvick, А. (1997) Crystal structure of the zeolite mutinaite, the natural analogue of ZSM-5. Zeolites, 19, 323-325.

Wells, S.A., Dove, M.T., Tucker, M.G. and Trachenko, K. (2002) Real-space rigid-unit-mode analysis of dynamic disorder in quartz, cristobalite and amorphous silica. Journal of Physics of Condensed Matter, 14, 4645-4657.

Wells, S.A., Dove, M.T. and Tucker, M.G. (2004) Reverse Monte Carlo with geometric analysisRMC+GA. Journal of Physics of Condensed Matter, 37, 536-544.

Wells, S.A., Sartbaeva, A. and Gatta, G.D. (2011) Flexibility windows and phase transitions of ordered and disordered ANA framework zeolites. Europhysics Letters, 94, 56001.

Werner, S., Barth, S., Jordan, R. and Schulz, H. (1996) Single crystal study of sodalite at high pressure. Zeitschrift für Kristallographie, 211, 158-162.

Zanazzi, P.F. and Pavese, A. (2002) Behavior of micas at high pressure and high temperature. Pp 99-116 in Micas: Crystal Chemistry and Metamorphic Petrology (A. Mottana, F.P. Sassi, J.B. Thompson Jr. and S. Guggenheim, editors). Reviews in Mineralogy \& Geochemistry, 46. Mineralogical Society of America and the Geochemical Society, Washington, DC.

Zhang, L., Ahsbahs, H. and Kutoglu, A. (1998) Hydrostatic compression and crystal structure of pyrope to $33 \mathrm{GPa}$. Physics and Chemistry of Minerals, 25, 301-307. 
